\title{
Land use/land cover classification and its change detection using multi-temporal MODIS NDVI data
}

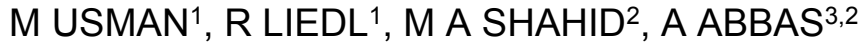 \\ 1. Institute for Groundwater Management, TU Dresden, 01069 Dresden, Germany; 2. University of Agriculture, \\ Faisalabad, Pakistan;3. Leibniz Centre for Agricultural Landscape Research (ZALF), Eberswalder Str. 84, \\ 15374, Müncheberg, Germany
}

Abstract: Detailed analysis of Land Use/Land Cover (LULC) using remote sensing data in complex irrigated basins provides complete profile for better water resource management and planning. Using remote sensing data, this study provides detailed land use maps of the Lower Chenab Canal irrigated region of Pakistan from 2005 to 2012 for LULC change detection. Major crop types are demarcated by identifying temporal profiles of NDVI using MODIS $250 \mathrm{~m}$ $\times 250 \mathrm{~m}$ spatial resolution data. Wheat and rice are found to be major crops in rabi and kharif seasons, respectively. Accuracy assessment of prepared maps is performed using three different techniques: error matrix approach, comparison with ancillary data and with previous study. Producer and user accuracies for each class are calculated along with kappa coefficients (K). The average overall accuracies for rabi and kharif are $82.83 \%$ and $78.21 \%$, respectively. Producer and user accuracies for individual class range respectively between $72.5 \%$ to $77 \%$ and $70.1 \%$ to $84.3 \%$ for rabi and $76.6 \%$ to $90.2 \%$ and $72 \%$ to $84.7 \%$ for kharif. The $\mathrm{K}$ values range between 0.66 to 0.77 for rabi with average of 0.73 , and from 0.69 to 0.74 with average of 0.71 for kharif. LULC change detection indicates that wheat and rice have less volatility of change in comparison with both rabi and kharif fodders. Transformation between cotton and rice is less common due to their completely different cropping conditions. Results of spatial and temporal LULC distributions and their seasonal variations provide useful insights for establishing realistic LULC scenarios for hydrological studies.

Keywords: land use/land cover; remote sensing; normalized difference vegetation index; accuracy assessment; change detection; hydrological modeling

J. Geogr. Sci. 2015, 25(12): 1479-1506

DOI: $10.1007 / s 11442-015-1247-y$

\section{Introduction}

Land cover is the most important property of earth's surface defining its physical condition and biotic component; whereas land use is the modification of land cover as per human needs and actions (Prakasam, 2010). Similarly, identifying these modifications in Land Use/Land Cover (LULC) over times and not over times is known as its change detection (Anderson, 1977). Rapid changes in LULC are observed throughout the world especially in developing countries due to their heavy reliance on agricultural production and increasing population. These changes necessitate the availability of improved and updated LULC datasets (Wardlow et al., 2007) for effective planning and production management, thus facilitating both farmers and policy makers (Liang et al., 2013).

Use of LULC data is highly acknowledged for water resources management (Schilling et 
al., 2008), through their extensive applicability for hydrological modeling studies. Water accounting is essential input in hydrological modeling and its accurate assessment is only possible with precise LULC mapping (Dappen et al., 2008; Molden, 1997). Moreover, information on areal extent of crops (especially irrigated crops), their types, and locations is very critical for estimating crop consumptive water use having varying crop water demand (Zheng and Baetz, 1999). In addition, as the parameters of lumped hydrological models cannot explicitly account for the variability within individual sub-basins in watershed due to missing spatial input data, this issue can be handled through the use of distributed models. In this case, impacts of LULC change represent the overall change as well as its spatial distribution (Kimaro et al., 2005).

Conventionally, LULC data in many developing countries including the current study region is available without much detail on their spatial distribution. The use of these data does not yield realistic LULC scenarios, thus leading to fussy inferences regarding management of total available water resources in different regions. This increasing demand for LULC information due to its ability in capturing spatial distribution at higher resolutions cannot be fulfilled through intensive ground surveys. Two facts are noteworthy in this regard. Firstly, the spatio-temporal changes of LULC are extremely quick particularly for irrigated areas which are beyond the scope of ground surveys. Secondly, the ground surveys are comparatively expensive, as well. This situation demands development of modern methodologies for collection and estimation of different LULC data from larger areas within short time durations (Osborne et al., 2001).

The deficiency in LULC data is overcome by the introduction of modern remote sensing data for agriculture use. Use of satellite remote sensing data is in practice since the 1970s in monitoring LULC changes at coarser spatial scales (Shao et al., 2001). Nevertheless, its use in irrigated agriculture has gained much popularity in recent years. For example, extensive research work has been done to map rice cultivated areas worldwide in the late 1980s and early 1990s for its use in climatic and trace gas emission studies. These datasets were available at coarser spatial resolution $\left(0.5^{\circ}\right.$ to $\left.5^{\circ}\right)$ (Matthews et al., 1983; Oslon, 1994). Mapping of global rice area at a spatial scale of 5 arc minutes (Leff et al., 2004) and rice mapping for south Asian countries using MODIS data are the new additions in recent past in this field (Xiao et al., 2006). Apart from rice mapping, several land cover databases have also been developed. These databases classify target areas into a number of classes of interest. The most recent development in this regard is the preparation of global land cover map by Gong et al. (2013) using $30 \mathrm{~m} \times 30 \mathrm{~m}$ Landsat Thematic Mapper (TM) and Enhanced Thematic Mapper Plus (ETM+) data. Table 1 presents a brief overview of some prominent local/regional land cover datasets developed over time.

Table 1 Summary of selected regional to country level Land Use/Land Cover datasets

\begin{tabular}{cllll}
\hline Sr. No & $\begin{array}{c}\text { Name of the } \\
\text { dataset }\end{array}$ & \multicolumn{1}{c}{ Data description } & Source & $\begin{array}{c}\text { Coverage/ } \\
\text { Spatial scale }\end{array}$ \\
\hline 1 & FAOSTAT & Agricultural lands & http://faostat3.fao.org/home/E & Country level \\
2 & FORIS & Inland waters, forest and woodland & $\begin{array}{l}\mathrm{http} / / \text { www.fao.org/forestry/sit } \\
\mathrm{e} / \mathrm{fra} / \mathrm{en}\end{array}$ & Country level \\
3 & GLCC & $\begin{array}{l}\text { Built-up areas, water resources, barren } \\
\text { http://edc2.usgs.gov/glcc/glcc.p }\end{array}$ & $1 \mathrm{~km} \times \mathrm{I} \mathrm{km}$ \\
& & grasslands, open shrub lands, forests & &
\end{tabular}




\begin{tabular}{|c|c|c|c|c|}
\hline 4 & GLCC-2000 & $\begin{array}{l}\text { Forests, cultivated and managed areas, } \\
\text { bare areas, water bodies, urban and } \\
\text { built-up areas }\end{array}$ & http://forobs.jrc.ec.europa.eu/ & $1 \mathrm{~km} \times 1 \mathrm{~km}$ \\
\hline 5 & $\begin{array}{l}\text { MOD12Q1 Land } \\
\text { Cover and Land } \\
\text { Cover Dynamics } \\
\text { products }\end{array}$ & Land cover change vectors & $\begin{array}{l}\text { http://modis.gsfc.nasa.gov/abo } \\
\text { ut/ }\end{array}$ & $500 \mathrm{~m} \times 500 \mathrm{~m}$ \\
\hline 6 & GISS & Forests, cultivated land and grasslands & $\begin{array}{l}\text { http://data.giss.nasa.gov/landu } \\
\mathrm{se} /\end{array}$ & $1^{\circ}(\approx 111 \mathrm{~km})$ \\
\hline 7 & GLCF & $\begin{array}{l}\text { Land tree cover, forest cover change, } \\
\text { Geo cover }\end{array}$ & $\begin{array}{l}\text { http://glcfapp.glcf.umd.edu: } 80 \\
\text { 80/esdi/index.jsp }\end{array}$ & $500 \mathrm{~m} \times 500 \mathrm{~m}$ \\
\hline 8 & PELCOM & $\begin{array}{l}\text { Coniferous, deciduous and mixed } \\
\text { forests, grassland, } \\
\text { rainfed and irrigated arable land, } \\
\text { perennial crops, shrub, barren land, } \\
\text { ice and snow cover, wetlands, inland } \\
\text { waters, sea and urban area }\end{array}$ & $\begin{array}{l}\text { www.geo- } \\
\text { informatie.nl/projects/pelcom/ } \\
\text { public/index.htm }\end{array}$ & $\begin{array}{l}1 \mathrm{~km} \times 1 \mathrm{~km} \\
(\text { Covers only } \\
\text { European } \\
\text { countries) }\end{array}$ \\
\hline & $\begin{array}{l}\text { Global land } \\
\text { cover map }\end{array}$ & $\begin{array}{l}\text { Cultivated areas, built-up lands, forests, } \\
\text { barren lands, etc. }\end{array}$ & $\begin{array}{l}\text { Yu et al. (2013); Gong et al. } \\
\text { (2013) }\end{array}$ & $30 \mathrm{~m} \times 30 \mathrm{~m}$ \\
\hline
\end{tabular}

The major limitations of using many of these datasets are their coarser spatial resolution and missing details on LULC at local or sub-basin level (Portmann et al., 2010) being only suitable at regional or global level. Moreover, some crop-specific land use maps do not cover the current study region including rice maps developed by Xiao et al. (2006) and Shao et al. (2001). In addition, regional LULC mapping done in the 1970s and 1980s (Wilson and Henderson-Sellers, 1985) is very old and based on diverse data sources. The relatively newer mapping of different LULC in Indus Basin has been carried out for the year 2007 by Cheema and Bastiaanssen (2010) at a spatial resolution of $1 \mathrm{~km} \times 1 \mathrm{~km}$ using Satellite Probatoire d'Observation delaTerre (SPOT) vegetation data. At this spatial resolution, problems may arise for complex cropping which may not be well-represented even at a spatial resolution of $1 \mathrm{~km} \times 1 \mathrm{~km}$. Under these circumstances, there is a felt need to develop detailed local LULC data at higher spatial scales for accommodating crop heterogeneity of complex cropping systems prevailing in the Rechna Doab.

To date, a number of earth observation satellites have been launched with varying degrees of resolution, i.e. Advanced Very High Resolution Radiometer (AVHRR) bearing coarse spatial resolution by National Oceanic and Atmospheric Administration (NOAA) while MODIS, Land Satellite (Landsat), and Advanced Space-borne Thermal Emission and Reflection Radiometer bear fine resolutions (ASTER) (Lu et al., 2013; Xiao et al., 2006). Some pros and cons are associated with each type of program. Only few images are available from Landsat per year, while ASTER charges fee for retrieving data. Many studies on LULC mapping have been carried out using a single-date imagery acquired from medium-to-higher resolution optical sensors such as ASTER, Landsat Thematic Mapper (TM), and SPOT (Niu et al., 2012; Fisher, 2010; Mitrakis et al., 2011). However, the temporal coverage of detailed LULC classes is still unexplored and is accomplishable by using images from MODIS that provides cost-free data including NDVI data after each 8 to 16 days at a higher spatial resolution of $250 \mathrm{~m} \times 250 \mathrm{~m}$. This resolution is high enough in capturing almost all major crop classes in the current study region for precise measurement of crop water requirements and subsequent water allocation planning for various parts of irrigated agricultural regions (Douglas et al., 2013; Jeong et al., 2011; Peng et al., 2011). The LULC mapping results by Cheema and Bastiaanssen (2010) exhibit an overlap of NDVI trends within different classes at 
certain crop stages thus making classification process tedious due to the use of single day data. This issue complicates further in case of multi-cropping system with varying crop scheduling (Gumma et al., 2011). Thus multi-temporal NDVI data not only facilitate classification process but also help in identifying various dates of crop stages within a growing season (Julien and Sobrino, 2009). With this background, this particular study presents a methodology for the classification of major LULC classes within complex cropping system of Lower Chenab Canal (LCC), Punjab, Pakistan's irrigated areas by combining satellite-derived NDVI time series data with $250 \mathrm{~m} \times 250 \mathrm{~m}$ spatial resolution as well as the ground information and agronomist opinion on phenology of the crops. The information is applied to identify different cropping patterns for each cropping season from year 2005 to 2012. This information is further used for assessing real patterns of water use along with exploring different LULC change scenarios for major crops by evaluating maximum flexibility of change within the study period. The specific objectives of this study are:

(1) Classification of major LULC and their accuracy assessment in complex irrigated lands of LCC at a higher spatial resolution.

(2) Study of relationship of orography and climatic factors with NDVI and estimation of areal extents of different LULC classes for individual cropping seasons.

(3) Detection of spatial and temporal LULC changes for exploring maximum flexibility of change for major classes. (or: in case of major crops).

The remainder of the manuscript is divided into three main sections. The first section describes the study area, Lower Chenab Canal (LCC), Punjab, Pakistan. The next section presents details on different input data types and methodology for LULC classification. The last section deals with the discussion on classification results, its accuracy assessment and other details including areal coverage and change detection for major LULC classes and its utilization for LULC scenarios generation.

\section{Materials and methods}

\subsection{Study area}

The LCC irrigation system was designed in 1892-1898 in the Punjab Province, Pakistan. Its command area is about 1.24 million ha (Mha) situated in Rechna Doab, a land between rivers Ravi and Chenab. This area lies between $30^{\circ} 36^{\prime}-32^{\circ} 09^{\prime} \mathrm{N}$ and $72^{\circ} 14^{\prime}-77^{\circ} 44^{\prime} \mathrm{E}$. The whole LCC area is divided into two parts, i.e., LCC East and LCC West. This study focuses on LCC East mainly comprising of Faisalabad (FSD) and Toba Tek Singh (TTS) districts. Administratively, the area is further divided into subunits called irrigation subdivisions (Figure 1) supervised by a sub-engineer. Ten irrigation subdivisions are studied in the study area for this research. A canal network supplies irrigation water to each subdivision separately. As water allocation to each irrigation subdivision varies within LCC, there is tremendous variability of groundwater and surface water use. 


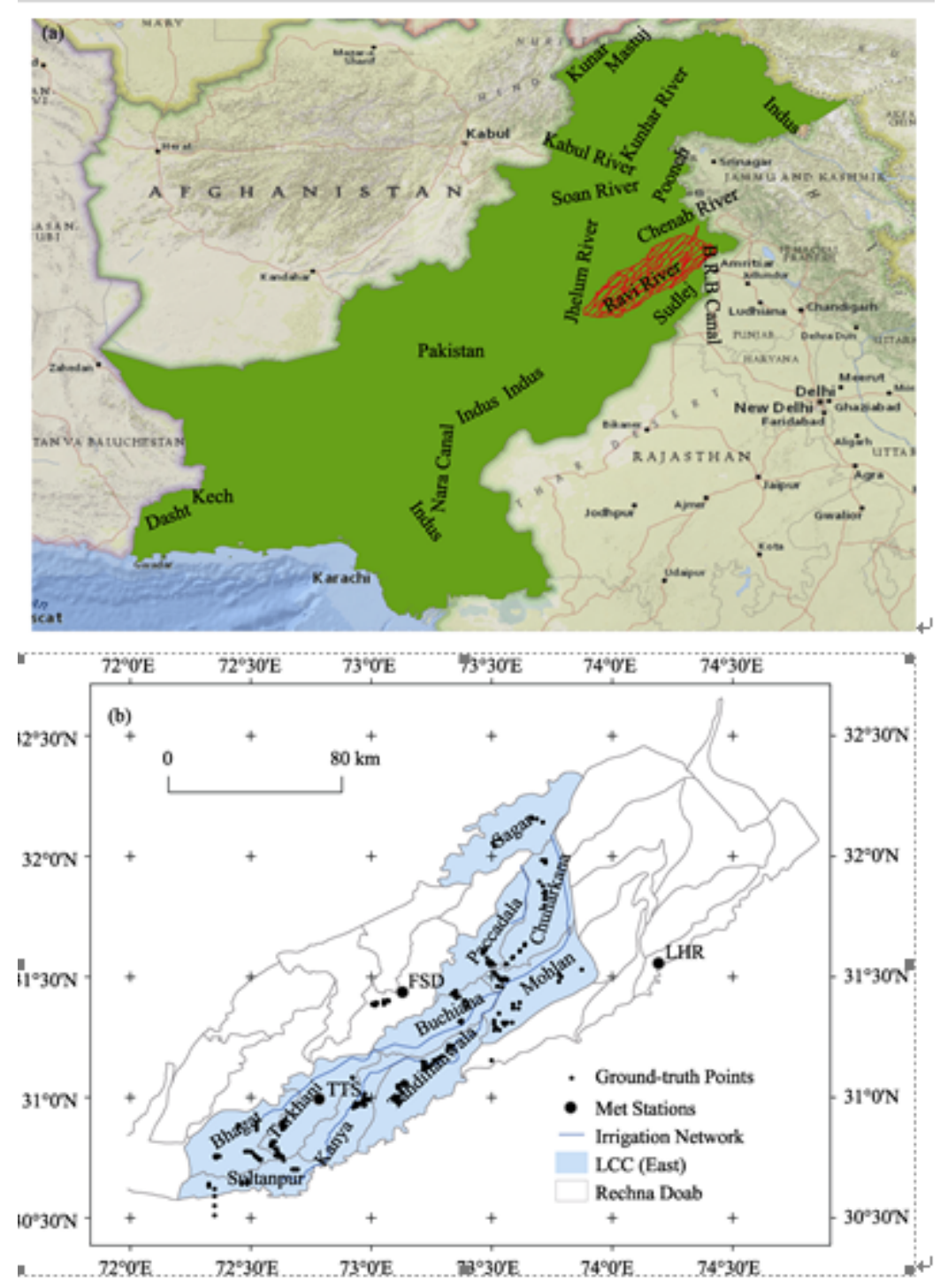

Figure 1 Map of LCC (East), Rechna Doab, Punjab, Pakistan and ground truthing points

The climate of the area is characterized by large seasonal fluctuations in temperature and rainfall. The summer is hot lasting from April through October with temperatures between $21-50^{\circ} \mathrm{C}$, whereas winter (October-April) temperature ranges between $15-27^{\circ} \mathrm{C}$. The area is sub-tropical in nature with mean annual precipitation varying from $290 \mathrm{~mm}$ in the South to $1046 \mathrm{~mm}$ in the North. The highest rainfall occurs during the monsoon season in July-August accounting for about $60 \%$ of the total average annual rainfall.

\subsection{Cropping calendar in LCC}

LCC has two distinct growing seasons, i.e., rabi and kharif respectively falling in winter and summer. Wheat and rabi fodder (mainly barseem and oat) are grown in rabi, whereas rice, cotton and kharif fodder (mainly sorghum, maize and millet) are grown in kharif season. 
Sugarcane is the annual crop which is mainly cultivated in September and in February as well. Figure 2 depicts the crop calendar of major crops grown in LCC.

\begin{tabular}{ll|l|l|l|l|l|l|l|l|l|l|l|l|}
\hline Crop & Month & Jan & Feb & Mar & Apr & May & Jun & Jul & Aug & Sep & Oct & Nov & Dec \\
\hline Wheat & \multicolumn{3}{|c}{} \\
\hline Cotton & \multicolumn{3}{|c}{} \\
\hline Rice & \multicolumn{3}{|c}{} \\
\hline Rabi fodder & \multicolumn{3}{|c}{} \\
\hline Kharif fodder & \multicolumn{3}{|c}{} \\
\hline Sugarcane & \multicolumn{3}{|c}{} \\
\hline
\end{tabular}

Figure 2 Crop calendar adopted in LCC

\subsection{Classification, accuracy assessment and change detection of LULC}

Vegetation indices provide possibility to estimate vegetation cover based on large differences of reflectance between the near infrared (NIR) and the red (R) bands (Tucker, 1979). These indices include NDVI and Enhanced Vegetation Index (EVI). NDVI is more sensitive to chlorophyll activity, whereas EVI is linked with vegetation structural variation and hence useful in mapping of tropical forests (Gao et al., 2000). The present work employs NDVI data for the estimation of green biomass of different irrigated crops in the study area. Although NDVI does not directly classify different LULC rather time series NDVI patterns help in the demarcation of different classes based on their unique behavior in terms of peak trends and duration of phenological stages within a specific agro-ecosystem (Shi et al., 2013; Julien and Sobrino, 2009). According to Peng et al. (2011) and Morton et al. (2006), land cover changes and their patterns could be successfully mapped with a $250 \mathrm{~m} \times 250 \mathrm{~m}$ spatial resolution although the extraction of these parameters at this spatial resolution is somewhat unexplored (Barraza et al., 2013). Therefore, geometrically- and radiometrically-corrected NDVI images were retrieved from http://glovis.usgs.gov/ at a spatial resolution of $250 \mathrm{~m} \times 250 \mathrm{~m}$. This portal provides cost-free and duly corrected images from board-Terra and Aqua satellites after each 16 days but with a difference of 8 days. Thus, NDVI data for the whole study area for the period October, 2005 to March, 2012 were retrieved successfully.

The retrieved data were preprocessed including image-sub-setting and image-enhancement. Once the product was ready for further processing and analysis, a hierarchical crop classification approach was utilized. As a first step in this approach, Iterative Self Organizing Data Analysis Technique (ISODATA) of unsupervised classification (Tou and Gonzalez, 1974) was employed to reduce the spectral confusion among different LULC classes. This technique disintegrates the whole image into clusters and each pixel in the image is assigned to a particular cluster based on its arbitrary mean vector value. This algorithm also permits clusters to change from one iteration to the next, by merging, splitting and deleting. Finally, all pixels are re-classified into the revised set of clusters, and the process continues till there is no significant change in the cluster statistics or maximum number of iteration is reached (Campbell, 2002). For this study, LULC classification was performed with $99 \%$ convergence 
threshold and 100 iterations. Following ISODATA algorithm, further refining of results was facilitated by seeking agronomists' opinion considering different cropping patterns in the study area. NDVI temporal profiles were utilized to merge some classes and also to identify crop growth stages e.g., sowing and harvesting. Significant increase in NDVI represented initial crop growth stage while decrease in NDVI was identified as the end of growing season. Separate LULC classes were generated for both cropping seasons to cater for various crops grown during these seasons and to facilitate LULC change detection from one cropping season to the other. The details of the classification methodology are portrayed in Figure 3.

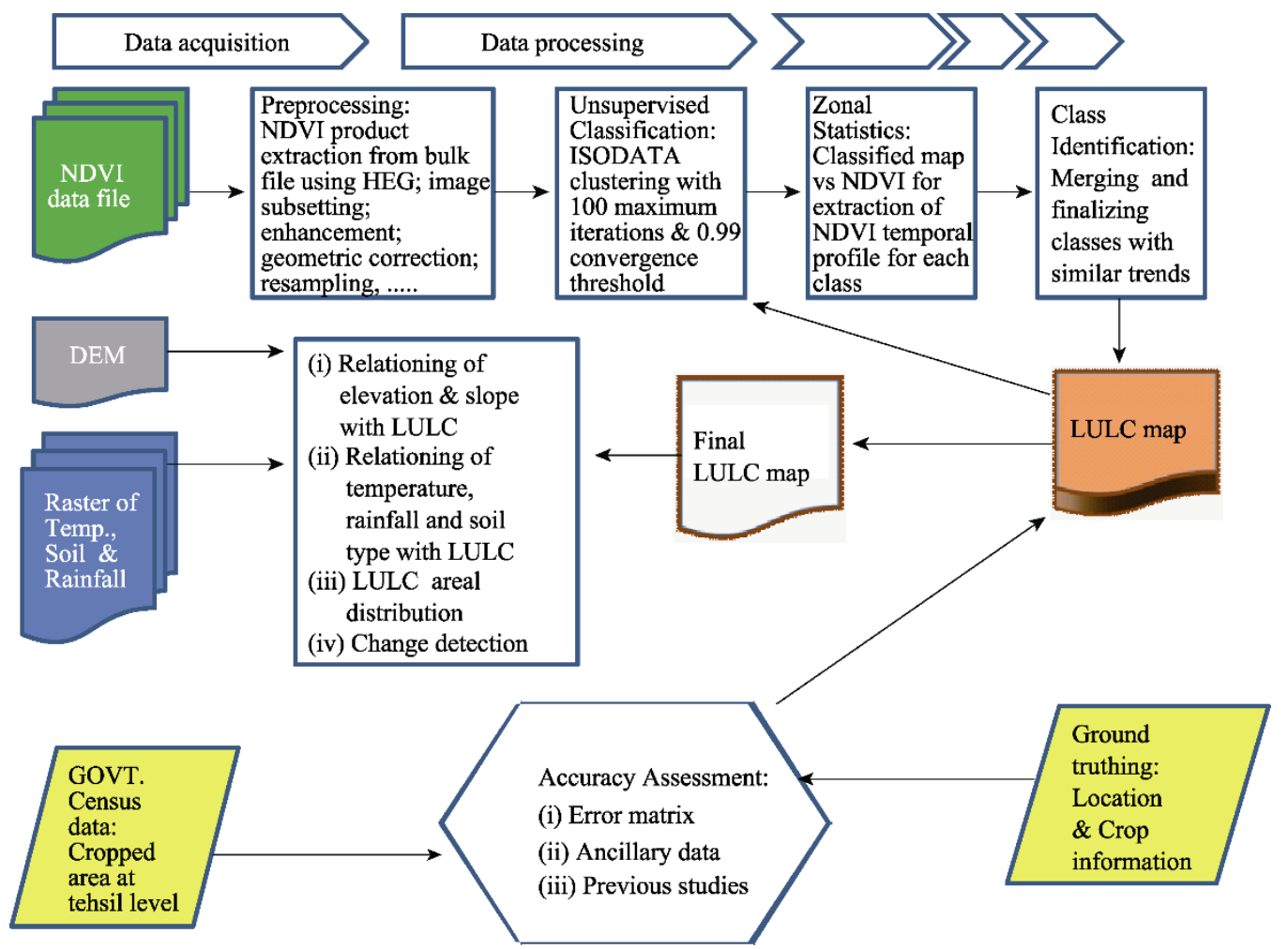

Figure 3 Flow diagram showing methodological and analytical steps

To explore the accuracy of the classification results, classical confusion matrix approach was employed along with comparison of results with ancillary dataset and previous empirical work in the study area. As confusion matrix approach uses reference data and precise information about the ground situation (Latifovic and Olthof, 2004), therefore, ground truthing points and polygons of different crops were ascertained with the help from water management officials within each district. GPS positioning of each field and crop-related information were recorded using a pre-designed questionnaire in a face-to-face discussion with farmers and experts (Figure 4). 

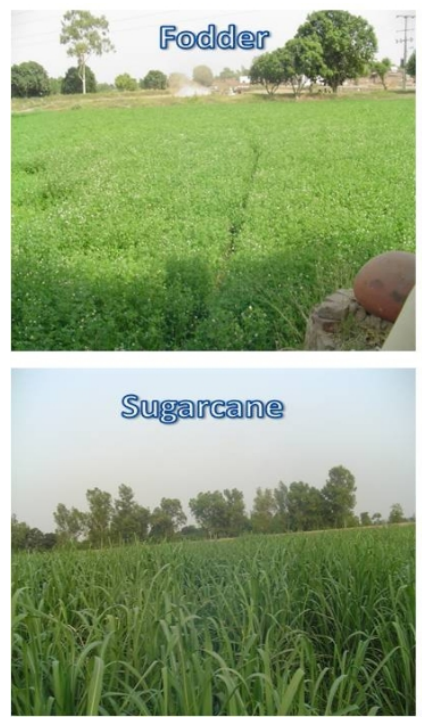
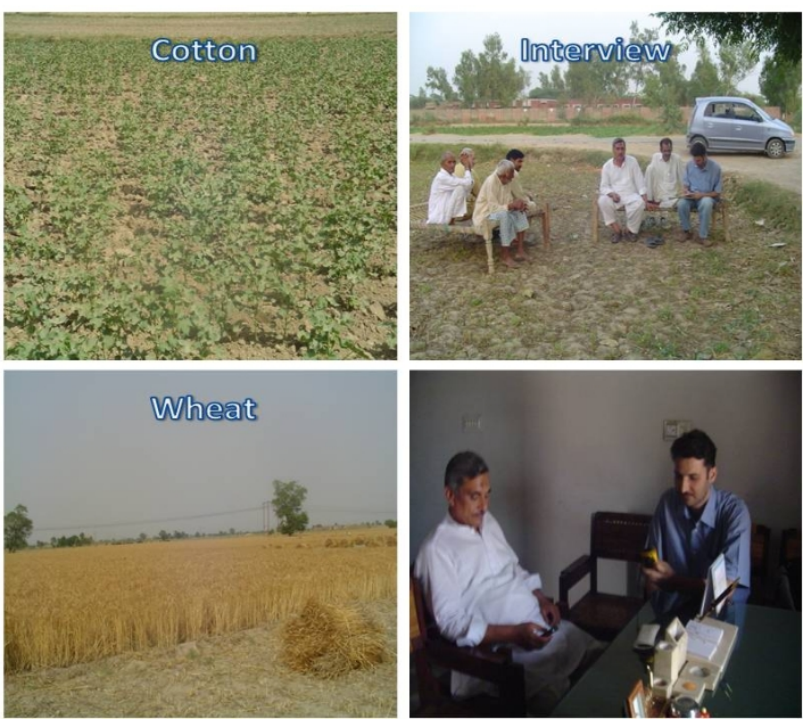

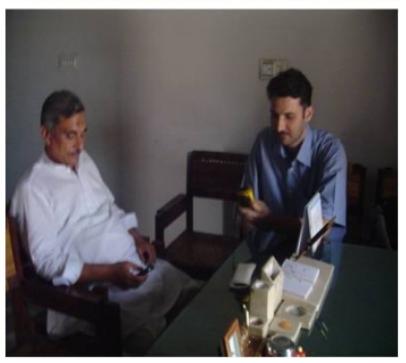

Figure 4 Highlights of the field visit in the study area

Similarly, for getting ancillary data on cropping area within the study area was gathered from relevant section of the provincial agriculture department. This department maintains complete record of cropped area under different crops at sub-district level (Tehsil). The reliability of estimates was corroborated by comparing area fractions of various crops at tehsil level with remote sensing data and statistically checked by coefficient of determination $\left(R^{2}\right)$. Another accuracy assessment was performed by comparing the classification results with the findings of relevant work in the study area.

To evaluate the effects of physical conditions (e.g. soil type, elevation, slope, temperature and precipitation) on major LULC classes, soil-type maps were obtained from the local office of International Water Management Institute (IWMI). The overlay analysis was performed between classified maps and soil maps using ArcGIS. Similarly, the effect of elevation and slope on LULC was accomplished using digital elevation model (DEM) with a resolution of $90 \mathrm{~m}$ acquired from http://glcf.umiacs.umd.edu/data/srtm/. Data regarding rainfall and temperature were collected for a number of climatic stations from Pakistan Meteorological Department (PMD). Average values of elevation, slope, temperature and rainfall were extracted for individual major LULC class to examine the spatial variability of these parameters in the study area.

Finally, areal distribution of each LULC class was calculated for both cropping seasons over the whole study period. Detection of spatial and temporal LULC changes was carried out for various crops to explore maximum range in change. Temporal changes were explored on the basis of overall difference of areas for various LULC between two particular cropping years, while spatial changes were explored on pixel-by-pixel scale to evaluate intra-class changes during these cropping years.

\section{Results and discussion}




\subsection{Classification of major LULC}

About 15 crop classes were identified by visualizing the trends of NDVI temporal profiles at first which reduced to nine by merging classes with similar NDVI trends keeping in view the crop calendar and expert's opinion. These classes are treated separately for both rabi and kharif cropping seasons. For rabi, wheat is the dominant crop cultivated on a vast area along with fodder (mainly berseem and mustard) while other crops are sugarcane, sparselycultivated orchards and vegetables. Demarcation of rabi fodders could not be attained due to their overlapping growth period with dominating wheat crop and hence NDVI exhibited higher overall values and similar trends for fodders and wheat. Furthermore, cultivated area for individual fodder is not available from any source to ensure maximum accuracy of classification. Resultantly, all fodders are merged to one class and hence four classes are demarcated for rabi seasons comprising of residence/fallow/barren, wheat, sugarcane and rabi fodder. Water is hardly distinguishable into a separate class due to its presence in relatively narrow irrigation channels under a spatial resolution of $250 \mathrm{~m} \times 250 \mathrm{~m}$. Employing ISODATA clustering algorithm at the $250 \mathrm{~m} \times 250 \mathrm{~m}$ spatial resolution, five LULC classes were demarcated for kharif season including rice, cotton, sugarcane, kharif fodder and residence/fallow/barren. A three period moving average filtering technique suggested by Reed et al. (1994) is used for smoothening of NDVI trends for each LULC class (Figure 5).

Two peaks and two depressions in one cropping year are observed in Figure 5. The first peak corresponds to the maximum growth period of wheat during February to March. The second peak corresponds to rice at its maximum growth in the mid of August. The two depressions appear at the end of April (at wheat harvesting) and before the start of November (before wheat sowing). The individual crops' starting time and crop-cycle length can be visualized easily from NDVI trends as well. Wheat sowing starts after the second week of November in the study area while NDVI becomes maximum around mid of February (Wajid et al., 2007). Berseem (rabi fodder) is cultivated in late November or in the beginning of December and its growth remains suppressed initially and then attains maximum height in late February and early March due to relatively increased temperature and rainfall. Sugarcane is mostly cultivated in September and sometimes also in February. Its trend remains static and low during the rabi season and attains higher values in kharif season due to increased vegetative growth. The 'Residence/Fallow/Barren' class has the least NDVI values throughout the year owing to low reflectance, which is in accordance with the previous findings by Pettorelli (2013). He found very low positive values of NDVI (0.1 or less) for barren areas of rock, sand or snow; and $0.1-0.2$ for soils. Most vegetation has moderate NDVI values $(\sim 0.2-0.5)$ while dense forests show high NDVI values $(\sim 0.6-0.9)$. The class 'rice' in kharif season has a very unique trend. The initial part is a bit slack and lengthy because of rice nursery growth from end of May to mid of June; whereas the later part attains maximum height due to rapid rice growth by the end of August.

Sugarcane and cotton are difficult to demarcate due to very similar NDVI trends seemingly because of September-sown sugarcane's height and rapid vegetative growth of cotton during mid and later stages of growing season (Wajid et al., 2010). Nevertheless, difference in sowing time of cotton from late May to mid-June facilitated the classification process and 


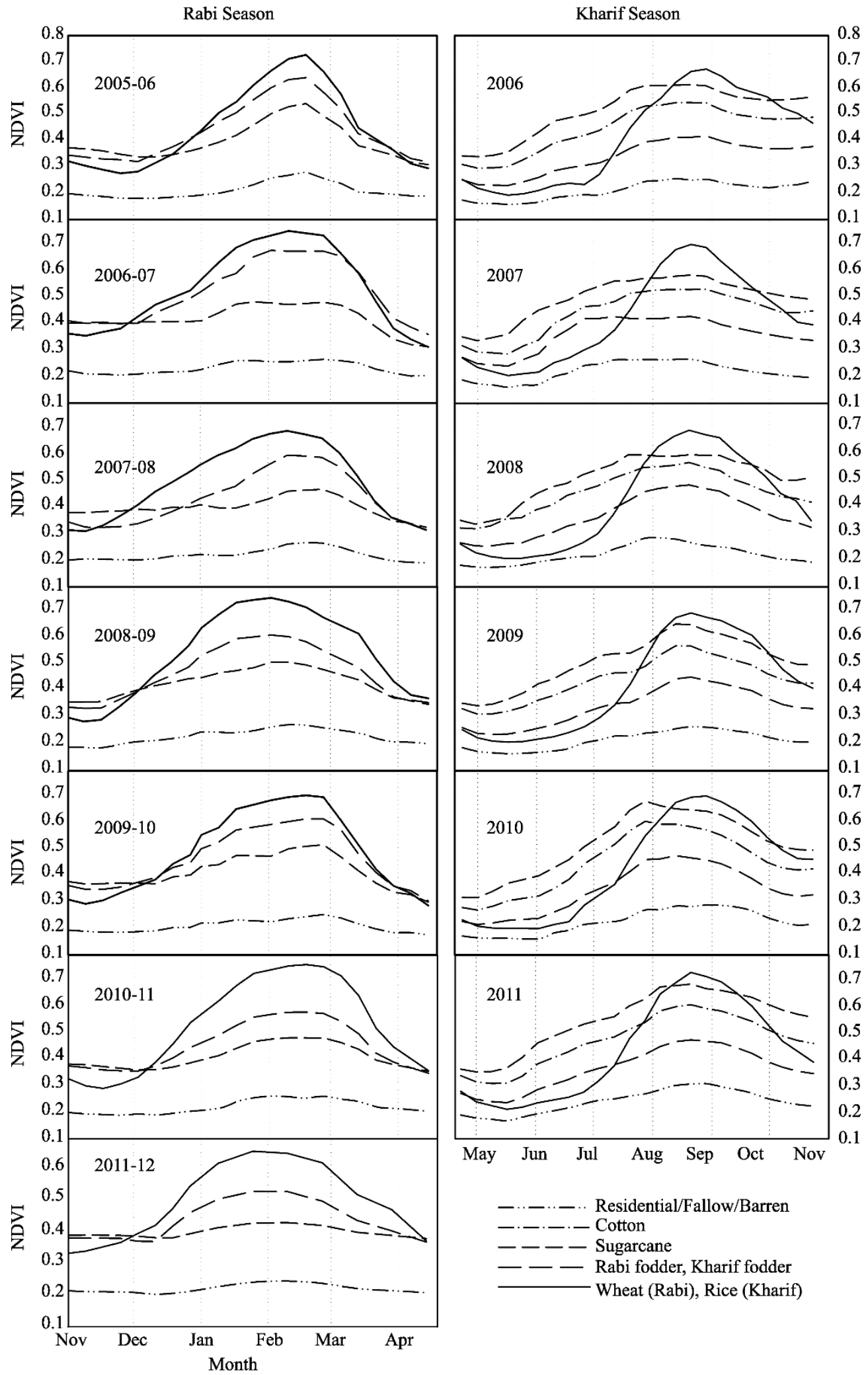

Figure 5 Mean NDVI temporal trends for major crops: rabi 2005-06 to rabi 2011-12 
its demarcation from sugarcane.

Results show that during different cropping years, a number of cropping patterns are adopted by the farmers in LCC, which include 'Wheat-Rice-Wheat', 'Wheat-Cotton-Wheat', 'Wheat-Sugarcane-Wheat', 'Wheat-Kharif Fodder-Wheat', and 'Rice-Kharif Fodder-Rice'. This scheme of cropping pattern is comparable with the actually prevailing system within the study area as explored during field visits.

\subsection{Assessing classification accuracy}

Accuracy assessment is an important component of LULC classification studies. The classification process is only considered to be reliable after meeting some accuracy checks as LULC maps derived from satellite images may contain some errors due to number of factors ranging from techniques in classification to satellite-data retrieval methods. We have employed a number of methods to ensure accuracy including error matrix, ancillary dataset and comparison with previous localized study.

\subsubsection{Error matrix}

Error matrix (also known as confusion matrix, correlation matrix or covariance matrix) is the most common and popular means to present accuracy results (Lu et al., 2013; Shi et al., 2013; Campbell, 2002). Many statistical measures of thematic accuracy can be drawn from the error matrix including overall accuracy, percentage of commission and omission error and the kappa coefficient (K) which address the error caused by chance (Congalton and Green, 1999). Commission error (i.e. user's accuracy) and omission error (i.e. producer's accuracy) take into account the probability of a particular cell value being similar with actual ground information and generated classified information, and vice versa, respectively. The overall classification accuracy summarizes the overall agreement or disagreement between classified and reference ground information about land use (Jensen, 1996) and is derived by using the following relationship:

$$
\text { Overall accuracy }=\frac{\text { number of s ampling classes clas sified correctly }}{\text { number of reference sampling classes }}
$$

Error matrices are constructed for the classified and actual ground information for different LULC classes. These error matrices reveal that overall accuracy for rabi seasons varies from $79.52 \%$ (minimum value) to $87.39 \%$ (maximum value) while for kharif seasons, it varies from $76.19 \%$ to $80.08 \%$. The overall average accuracy levels for rabi and kharif are $82.83 \%$ and $78.21 \%$, respectively. This range of accuracy is in accordance with the findings of Thi et al. (2012) and Wardlow et al. (2007). Moreover, Bastiannssen (1998a) has noted that overall accuracy ranges from $49 \%$ to $96 \%$ depending on the spatial coverage of satellite information and the size of the field under consideration. The average accuracies for producer and user are $78.62 \%$ and $77.87 \%$ for rabi and $79.95 \%$ and $76.70 \%$ for kharif, respectively. User's accuracy values affirm that $77.87 \%$ and $76.70 \%$ of all classes identified on the classified map for rabi and kharif, respectively, match with the ground information. On the other hand, the producer's accuracy values indicate that $78.62 \%$ and $79.95 \%$ of the actual LULC information matches with the classified results for LULC for rabi and kharif seasons, respectively.

The lowest and highest producer's accuracy values observed for 'sugarcane' are $70.83 \%$ (rabi 2005-06) and 86.15\% (rabi 2010-11). For 'rabi fodder' these values are $69.57 \%$ (rabi 
2006-07) and 78.18\% (rabi 2007-08). Lower values of producer's accuracies in different seasons for 'sugarcane' and 'rabi fodder' are possibly due to smaller plot sizes given $250 \mathrm{~m} \times$ $250 \mathrm{~m}$ of spatial resolution and mixed cropping pattern. In contrast, wheat is cultivated on large areas and hence has higher accuracy value. For kharif seasons, average producer's accuracies range between $76.59 \%$ for 'rice' and $90.24 \%$ for 'residence/fallow/barren' whereas the values for cotton, sugarcane and kharif fodder are $77.16 \%, 78.96 \%$ and $76.76 \%$, respectively. The lower accuracy values for kharif season also stems due to small plot sizes and blending of pixels due to mixed cropping pattern (Cheema and Bastiaanssen, 2010). The detail of producer's and user's accuracies for different LULC classes for each cropping year is presented in Table 2.

Table 2 Summary of producer's and user's accuracies for different classes of rabi and kharif seasons

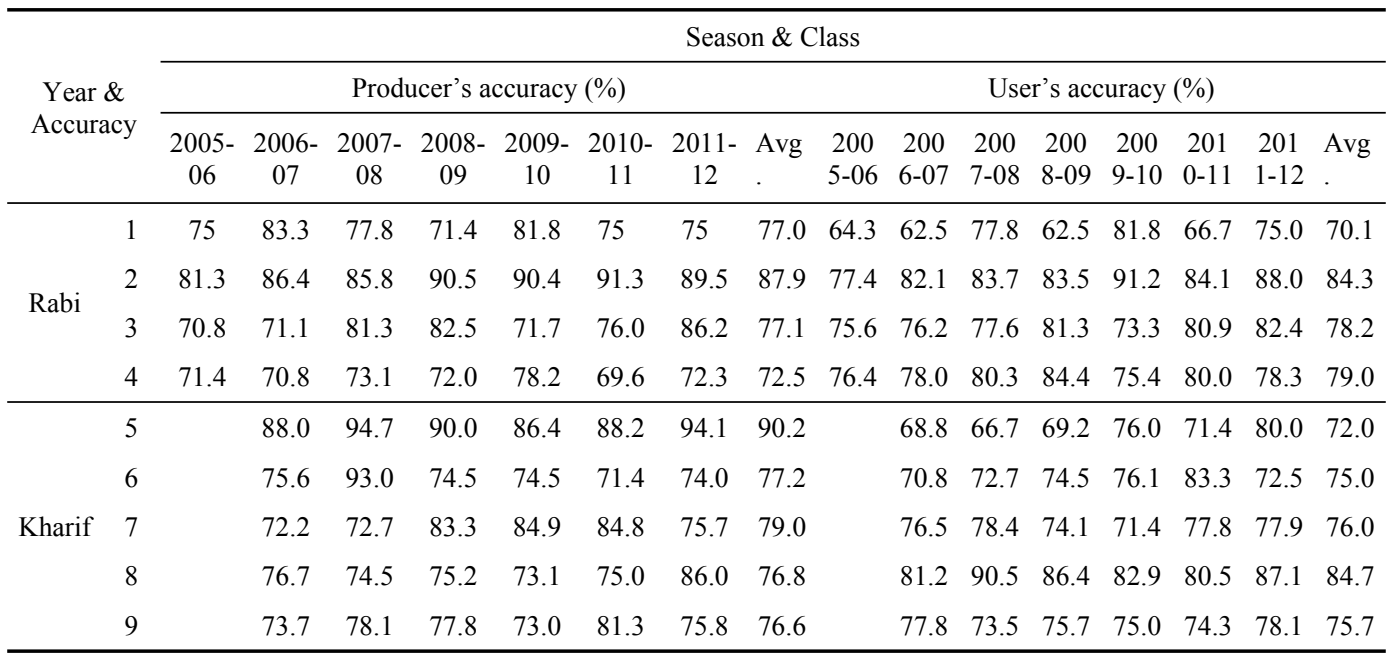

*Numbers in this column represent as follows: $1 \& 5=$ Residential/Fallow/Barren; $2=$ Wheat; $3 \& 7=$ Sugarcane; $4 \& 8=$ Fodder; 6=Cotton; 9=Rice

The overall classification efficiency provides a crude measure of accuracy (Giri et al., 2005) while accuracy assessment through error matrix depends on sampling points. Fewer sampling points may lead to misspecification of classes (Foody, 2002) which we can diagnose by estimating the kappa coefficient $(K)$ (Congalton, 1996). The value of $K$ incorporates the offdiagonal elements of the error matrices and exhibits agreement after removing the agreement by chance. The value of $K$ for each season is calculated as under and shown in Table 3.

$$
K=\frac{\text { percent overall correct valve - percent correct agreement to observed values }}{\text { total number of class - percent correct agreement to observed valves }}
$$

Comparison of estimated average values of $K$ (shown in Table 3 ) for present study with earlier studies (shown in Table 4) reveals a close match between the two.

Table 3 Summary of seasonal accuracies and $K$ (Kappa coefficient)

\begin{tabular}{ccccccccccc}
\hline & & \multicolumn{4}{c}{ Rabi Season } & \multicolumn{4}{c}{ Kharif Season } \\
\cline { 3 - 10 } Sr. & Year & $\begin{array}{c}\text { Avg. } \\
\text { Prod. } \\
\text { No. }\end{array}$ & $\begin{array}{c}\text { Avg. } \\
\text { Ascer }\end{array}$ & $\begin{array}{c}\text { Overall } \\
\text { Accur. }\end{array}$ & $K$ & $\begin{array}{c}\text { Avg. } \\
\text { Prod. } \\
\text { Accur. }\end{array}$ & $\begin{array}{c}\text { Avg. } \\
\text { User } \\
\text { Accur. }\end{array}$ & $\begin{array}{c}\text { Overall } \\
\text { accuracy }\end{array}$ & $K$ \\
\hline 1 & $2005-06$ & 74.7 & 73.4 & 87.4 & 0.77 & & & & \\
2 & $2006-07$ & 77.9 & 74.7 & 79.5 & 0.66 & 77.2 & 75.0 & 76.2 & 0.69
\end{tabular}




\begin{tabular}{lllllllllll}
3 & $2007-08$ & 80.6 & 80.4 & 83.6 & 0.74 & 82.6 & 76.4 & 79.3 & 0.73 \\
4 & $2008-09$ & 78.0 & 77.9 & 81.9 & 0.71 & 80.2 & 76.0 & 78.1 & 0.71 \\
5 & $2009-10$ & 79.5 & 79.9 & 81.2 & 0.71 & 78.4 & 76.3 & 77.0 & 0.70 \\
6 & $2010-11$ & 80.8 & 80.9 & 83.8 & 0.75 & 80.2 & 77.5 & 78.6 & 0.72 \\
7 & $2011-12$ & 79.0 & 77.9 & 82.5 & 0.74 & 81.1 & 79.1 & 80.1 & 0.74 \\
\hline
\end{tabular}

\subsubsection{Ancillary data}

Estimated and reported crop area fractions for major crops are measured with the help of remote sensing and ancillary data collected from provincial agriculture department. The estimated area fraction is calculated by dividing the remotely-sensed area for a particular crop

in a tehsil by the geographical area of that tehsil. Similarly, reported crop area fractions are measured by dividing each crop's area in tehsils to their total geographical area. The relationship of reported and estimated crop area fractions for major crops is presented in Figure 6 . The distribution of data points shows wheat to be the major crop in rabi occupying major area in all tehsils. A higher value for the coefficient of determination $\left(R^{2}=0.85\right)$ shows a higher reliability of this estimation (Figure 6). Other crops in the area include rabi fodder and sugarcane during rabi season. As the cultivation of sugarcane in various tehsils is not so high, most points fall around 0.20. Moreover, as the sugarcane lasts during both seasons, its crop area fraction is calculated for both seasons together having a coefficient of determination equal to 0.75 . This relatively small value stems from mixing with other crops due to large pixel size relative to field size along with ancillary data having low standard accuracy.

Table 4 Comparison of accuracy values and $K$ from earlier studies with present study

\begin{tabular}{cllll}
\hline Sr. No. & $\begin{array}{c}\text { Classification } \\
\text { accuracy }\end{array}$ & \multicolumn{1}{c}{$K$} & \multicolumn{1}{c}{ Type of data } & Reference \\
\hline 1 & 91.5 & 0.89 & RADARSAT & Shao et al., 2001 \\
2 & 77.2 & 0.736 & MODIS & Giri et al., 2005 \\
3 & $84.4-87.1$ & $82.3-83.6$ & Landsat MSS. ETM+ & Reis, 2008 \\
4 & 77 & 0.73 & SPOT & Cheema et al., 2010 \\
5 & 94 & 0.93 & SPOT & Thi et al., 2012 \\
6 & $78-99$ & - & Landsat & Ding et al., 2013 \\
7 & $84-93$ & $0.78-0.92$ & Landsat & Lu et al., 2013 \\
8 & $78.2-82.8$ & $0.71-0.73$ & MODIS & Present study \\
\hline
\end{tabular}

For kharif seasons, the relationship is observed for both cotton and rice. The coefficients of determination for cotton and rice are found to be 0.78 and 0.83 , respectively. Almost identical planting dates for various crops during this season make it difficult to discriminate these crops along with mixing of pixels and ancillary data quality. Nevertheless, values of $\mathrm{R}^{2}$ for different crops depict reliable and encouraging results given the complex cropping patterns prevailing in LCC.

\subsubsection{Comparison with localized study}

The third accuracy assessment technique used is the comparison of classification results with a previous localized study. Cheema and Bastiaanssen (2010) conducted a study to classify the whole Indus Basin into different LULC classes for the cropping year 2007. A map of LULC 
for LCC, being part of Indus Basin, was obtained from the quoted authors. This map is available at $1 \mathrm{~km} \times 1 \mathrm{~km}$ spatial resolution with non-separable classes for rabi and kharif seasons (Figure 7). This Figure shows the dominance of arable agriculture in the area. Rice and wheat are dominating crops in the upper parts of the study area during kharif and rabi seasons, respectively. Cotton is dominant in the downstream area along with sugarcane and fodder. The spatial details of areas under different major classes by Cheema and Bastiaanssen (2010) and the current study can be seen in Figure 7.
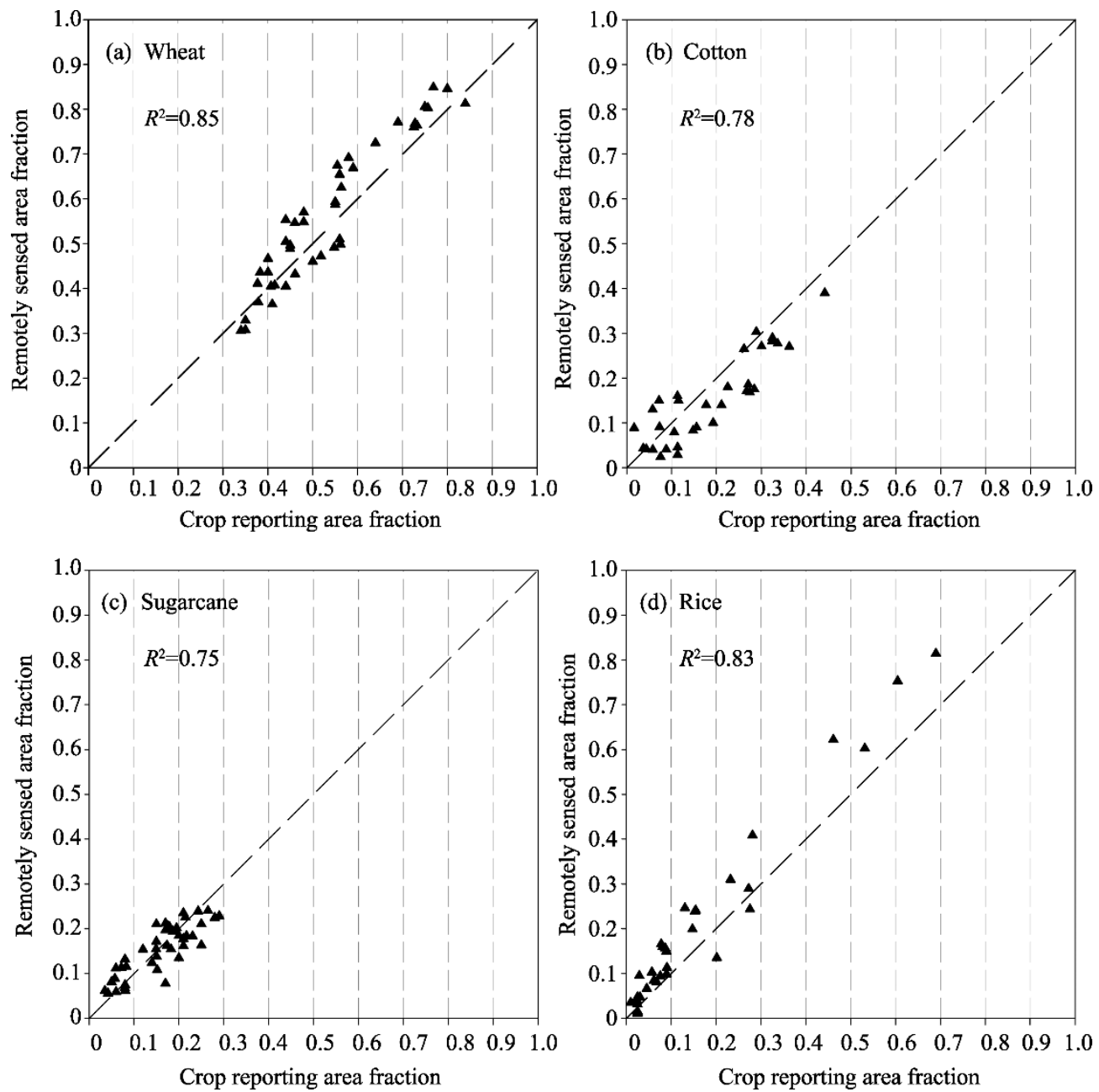

Figure 6 Relationship between reported cropped-area fraction and remotely-sensed cropped-areas fraction for wheat, cotton, sugarcane and rice crops (1:1 Plot)

\subsubsection{Orographic and climate effects on LULC}

Soil and orography have a great effect on adaptability of LULC in different parts of the world. Similarly, climate change influences the terrestrial biosphere closely linked with hydrological, carbon and energy cycles thus affecting vegetation indices to a great extent (Kim, 2013). Many studies depict this influence in many parts of the world including USA, India, China, Turkey and Indus Basin (Kim, 2013; Fang et al., 2005; Reis, 2008; Cheema and Bastiaanssen, 2010). For the present study, overlay analysis of soil map with LULC 
distribution revealed increased adaptability of wheat and sugarcane cultivation on moderatelyfine to moderately-coarse soils, while rice and cotton have more suitability with moderatelyfine and moderately-coarse soils, respectively (Table 5). Rabi and kharif fodders are mostly cultivated on moderately-coarse soils. Slope data from Table 5 indicate that the area is relatively flat with slopes ranging from $1.14 \%$ to $2.4 \%$. Rice is dominant at relatively higher slope and cotton at lower slope. The slope decreases from north-east to south-west of LCC. Rice and wheat are cultivated at relatively higher elevations, i.e., $192 \mathrm{~m}$ and $187 \mathrm{~m}$, respectively. As a matter of fact, wheat cultivation is common throughout the study area having much concentration in the northern parts. Sugarcane is found to be cultivated at the lowest elevation $(169 \mathrm{~m})$ mostly along the areas near river Ravi. There is no significant difference in mean elevation for cultivation of other crops.

(a) Cheema and Bastiannsen, 2010

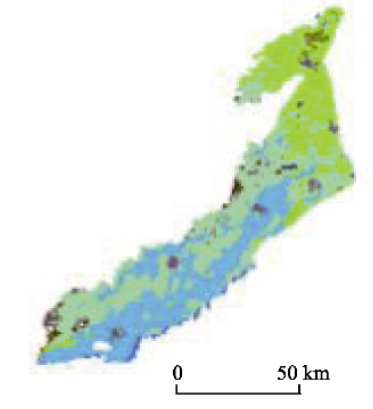

Class Name

26 Settlemets $(31000 \mathrm{ha})$

24 Rainfed crops general $(15000 \mathrm{ha})$

23 Rainfed crops mixed cotton, wheat rotation/ fodder ( $2500 \mathrm{ha})$

20 Irrigated rice/fodder rotation ( $242 \mathrm{ha}$ )

19 Irrigated wheat, fodder rotation ( $3000 \mathrm{ha})$

18 Irrigated mixed ricc, wheat rotation/cotton (7457 ha)

17 Irrigated rice wheat rotation (220220 ha)

16 Irrigation mixed cotton, wheat rotation/sugarcane ( $369292 \mathrm{ha})$

15 Irrigated mixed cotton, wheat rotation/fodder (29064 ha) (b) Present study (Kharif 2007)

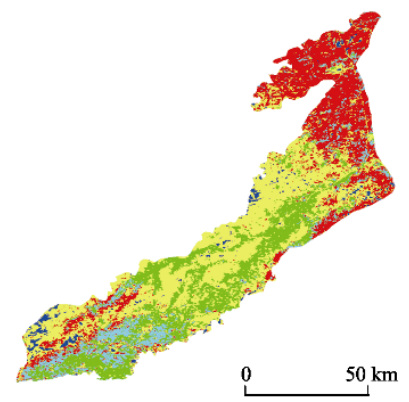

Class Name

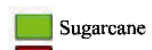

$\square$ Rice

$\square$ Fodder Kharif

$\square$ Cotton

$\square$ Resident/fallow/barren (c) Present study (Rabi 2007-08)

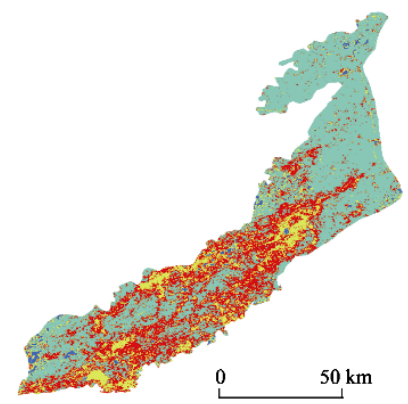

Class Name

$\square$ Wheat

$\square$ Sugarcane

Fodder Rabi

Resident/fallow/barren

Figure 7 Comparison of crop area estimates with Cheema and Bastiannssen (2010)

Among different climatic factors, rainfall and temperature are more linked with NDVI (Adam Black and Haroon Stephen, 2014; Kim, 2013). Present study investigated the effect of precipitation and temperature on NDVI for major crops in LCC. Temporal information for rainfall and temperature concerning each crop is extracted using zonal statistics function. As given by Figure 8, wheat is sown in the mid of November onward. Relatively higher temperature is observed for wheat in the initial stages with little rainfall. Later on, temperature decreases and rainfall increases between the months of February and March, thus causing increase in NDVI values in the middle of wheat growth. Temperature continues to increase towards the end of wheat growth and NDVI values continue to decrease till its harvest in the mid-April onward. These conditions best suit wheat production in the study area as revealed by the local crop experts, who opined that low temperatures at germination would suppress crop growth while high temperatures at mid stages (especially milking stage) would cause crop shriveling. The trends of temperature for cotton and rice crops during kharif are not 
very different and exhibit less fluctuation throughout the growing period but the major difference is observed in case of rainfall. In the cotton growing areas, less rainfall is observed at germination stages and then smoothly increases resulting into increase in NDVI trends. Completely contrasting situation prevails in rice-growing areas where rainfall is higher at the initial stages of crop growth, lasting till the end of monsoon season. Completely different cropping conditions of rice and cotton in respective areas partially explain variation in growth stages and allied benefits or disadvantages. Plenty of moisture is beneficial for rice cultivation, whereas rainfall at initial stages of cotton would form soil crust which hampers its germination. Similarly, local experts believe that higher temperature with lower precipitation has a detrimental effect on rice growth especially in its early stage while cooler nights towards the crop maturity help improve grain quality. The NDVI trend for sugarcane is very clear and indicates increasing NDVI values with increase in rainfall and vice versa. This NDVI trend is relatively static during winter months mainly due to lower temperature coupled with a smaller amount of rainfall during this time which suppresses sugarcane vegetative activity.

Table 5 Summary of soil texture, elevation and slope for each LULC

\begin{tabular}{|c|c|c|c|c|}
\hline Class Name & Texture Class & Texture & Elevation (m) & Slope $(\%)$ \\
\hline Wheat & $\begin{array}{l}\text { Moderately fine/ } \\
\text { Moderately-coarse }\end{array}$ & $\begin{array}{l}\text { Sandy-clay-loam, clay-loam, } \\
\text { silty-clay-loam/sandy-loam, } \\
\text { fine sandy-loam }\end{array}$ & 187 & 1.98 \\
\hline Rice & Moderately-fine & $\begin{array}{l}\text { Sandy-clay-loam, clay-loam, } \\
\text { silty-clay-loam }\end{array}$ & 192 & 2.40 \\
\hline Cotton & Moderately-coarse & Sandy-loam, fine sandy-loam & 176 & 1.14 \\
\hline Sugarcane & $\begin{array}{l}\text { Moderately } \\
\text { fine/Moderately-coarse }\end{array}$ & $\begin{array}{l}\text { Sandy-clay-loam, clay-loam, } \\
\text { silty-clay-loam/sandy-loam, } \\
\text { fine sandy-loam }\end{array}$ & 169 & 2.00 \\
\hline Rabi fodder & Moderately-coarse & Sandy-loam, fine sandy-loam & 175 & 1.41 \\
\hline Kharif fodder & Moderately-coarse & Sandy-loam, fine sandy-loam & 179 & 1.91 \\
\hline
\end{tabular}



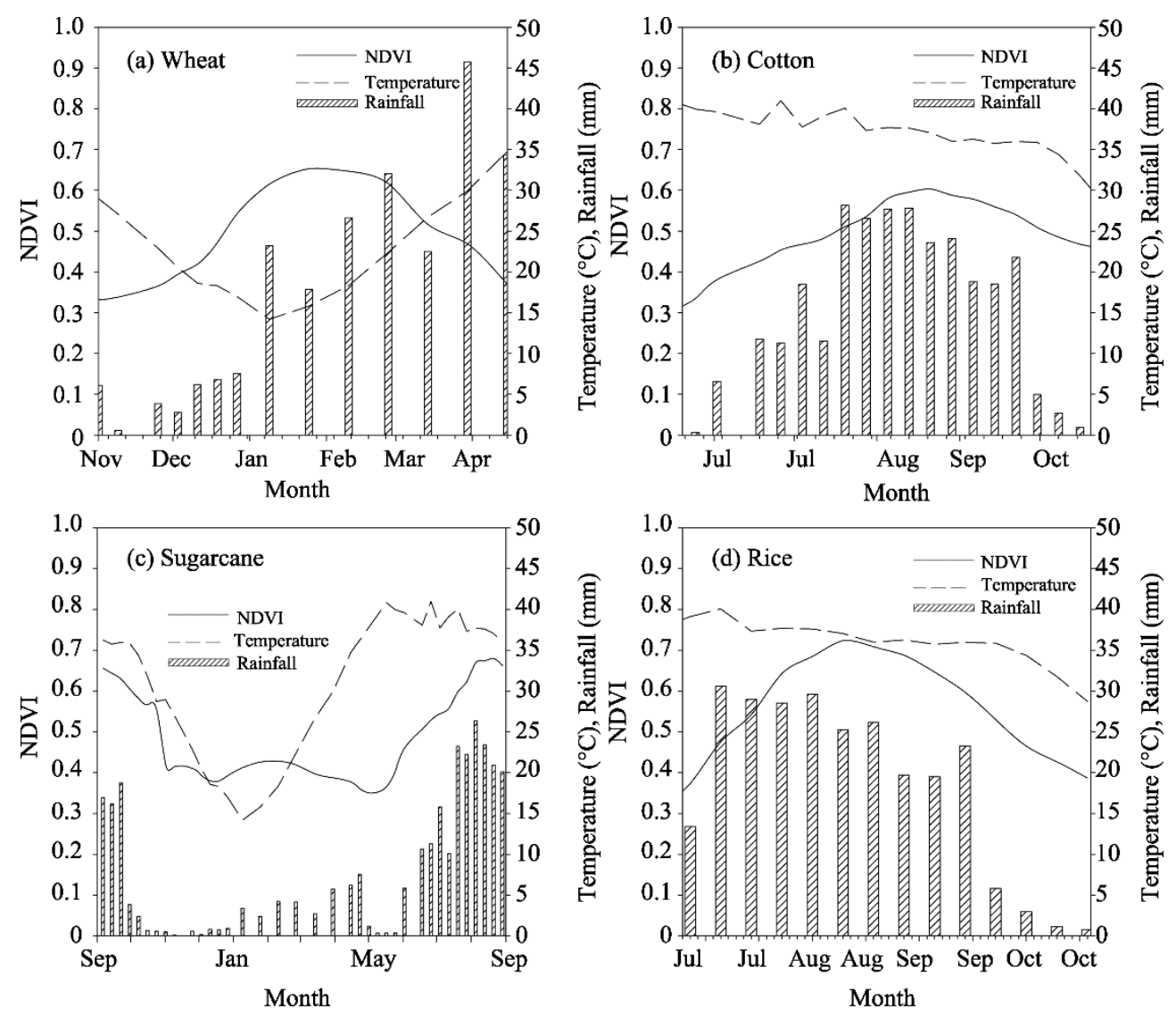

Figure 8 Relationship of NDVI to temperature and precipitation for wheat, cotton, sugarcane and rice

\subsubsection{Areal distribution of major crop classes}

Estimation of areal distribution for various crops forms one of the key informations for hydrological modeling especially in irrigated agriculture. Tables 6 and 7 show this areal distribution under different classes for both rabi and kharif seasons. During all rabi seasons, wheat is the major class in LCC with an overall cropped area of more than $50 \%$ with values ranging between 497,214 ha (53.7\%) in 2007-08 to 598,172 ha (64.6\%) in 2009-10. Rest of the area is occupied by rabi fodder and sugarcane with values ranging between 299,717 ha $(32.3 \%)$ to 128,328 ha (13.8\%) for sugarcane, and 214,061 ha $(23.1 \%)$ to 78,453 ha $(8.5 \%)$ for rice considering all study years.

Table 6 Areal distribution of LULC classes during rabi seasons in LCC

\begin{tabular}{|c|c|c|c|c|c|}
\hline Year & Class* & Area (ha) & Area (\%) $\square$ Fodder $\square$ Sugarcane & Wheat & afallow \\
\hline \multirow{4}{*}{$2005-06$} & 1 & 227300 & 24.5 & & \\
\hline & 2 & 128328 & \begin{tabular}{r|r} 
& 13.8 \\
\end{tabular} & & \multirow{3}{*}{59.2} \\
\hline & 3 & 548403 & V1 & & \\
\hline & 4 & 22042 & 2.4 & & \\
\hline \multirow{4}{*}{ 2006-07 } & 1 & 230410 & 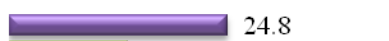 & & \multirow{4}{*}{59.5} \\
\hline & 2 & 124671 & 13.5 & & \\
\hline & 3 & 550848 & \multirow{2}{*}{2.2} & & \\
\hline & 4 & 20144 & & & \\
\hline
\end{tabular}




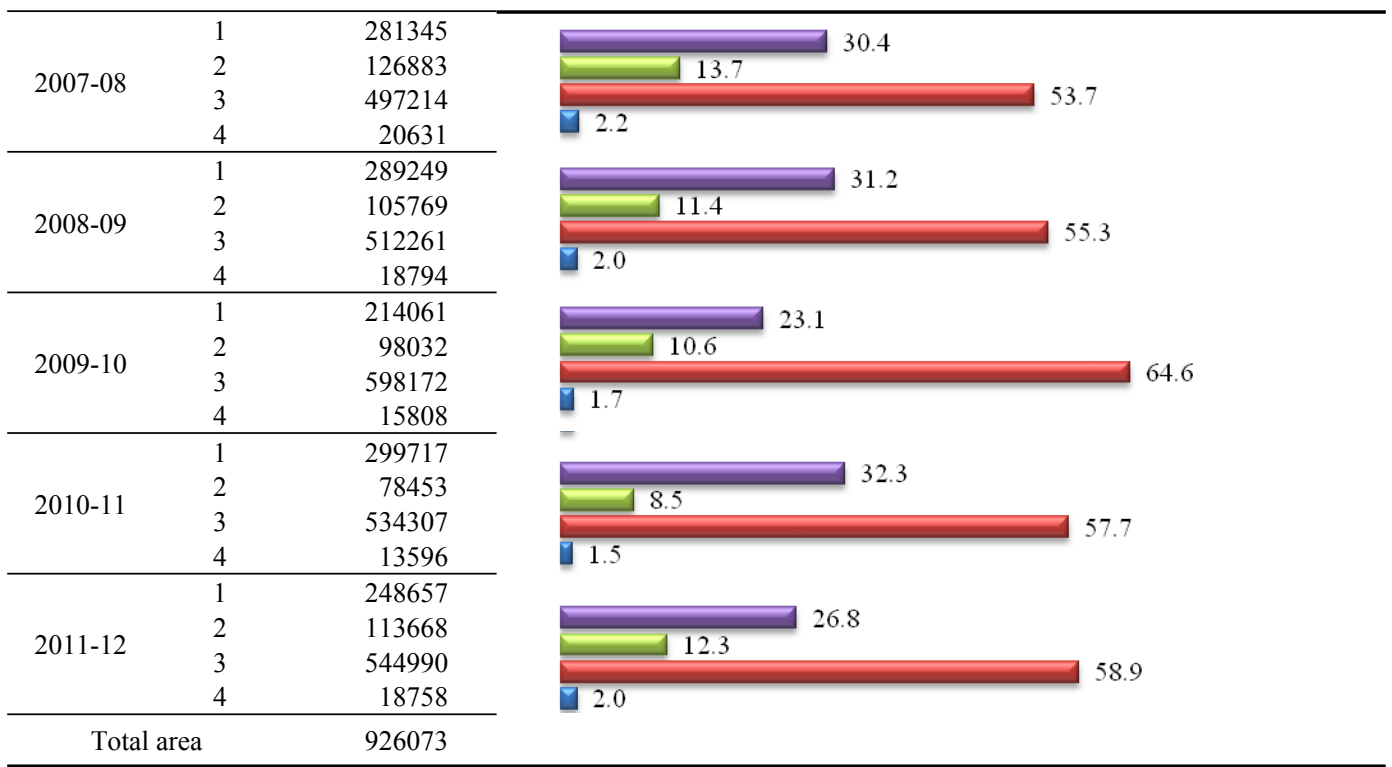

*Numbers in this column represent as follows: 1=Fodder; $2=$ Sugarcane; $3=$ Wheat; $4=$ Residential/Fallow/Barren

For kharif seasons, a distinctive pattern in crop cultivated area is observed at various intervals during the study period. The cultivation of rice has the least relative fluctuation in area with values in the range of 251,435 ha $(27.2 \%)$ and 361,944 ha (39.1\%). Maximum and minimum values for area of sugarcane are 198,419 ha (21.4\%) and 87,297 ha (9.4\%), respectively. The cultivated area under kharif fodder decreases from previous to current years while it is vice versa for cotton. Minimum and maximum values for kharif fodder are 169,562 ha $(18.3 \%)$ and 414,699 ha $(44.8 \%)$, respectively while for cotton, they are 76,740 ha $(8.3 \%)$ and 259,964 ha $(28 \%)$, respectively.

Table 7 Areal distribution of LULC classes during kharif seasons in LCC

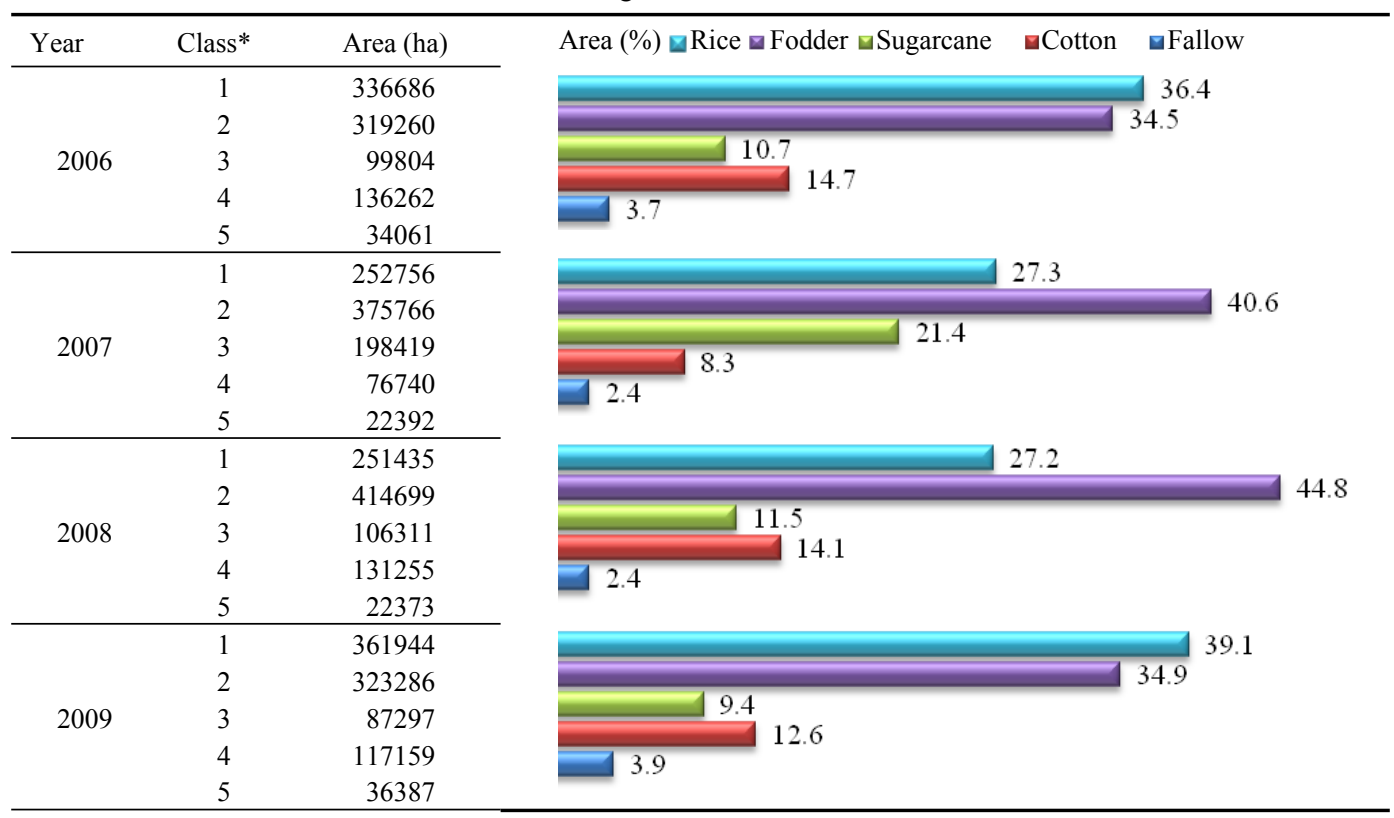




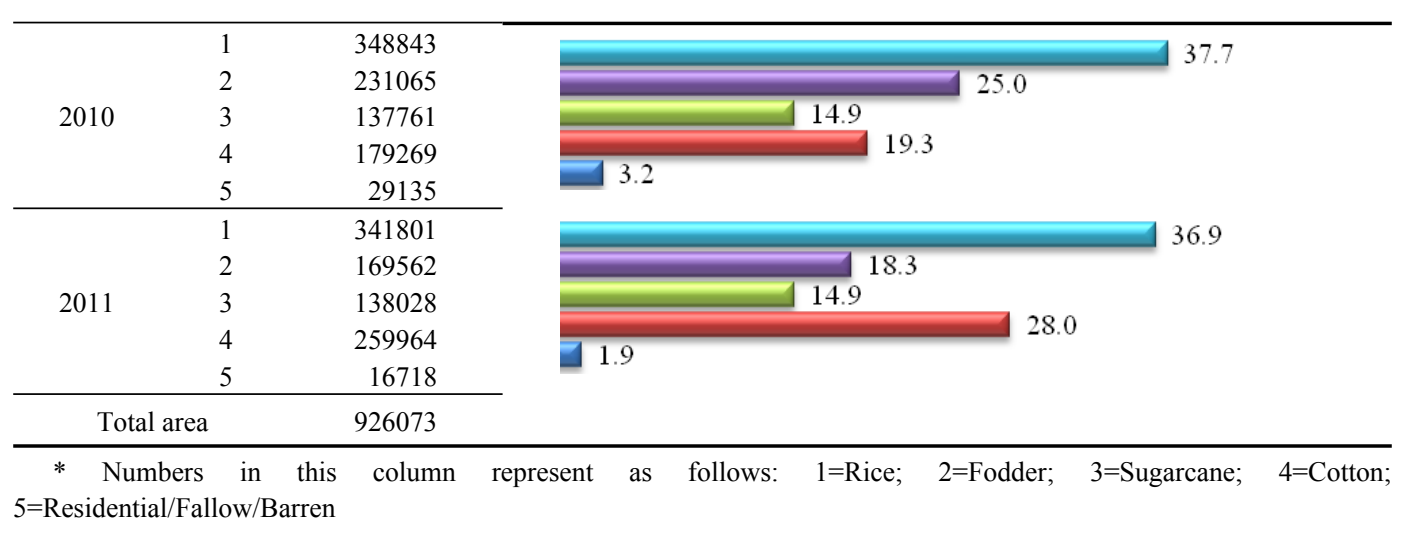

\subsubsection{LULC change detection}

Most studies on LULC change detection consider two well-separated years for this process (Lu et al., 2013; Ding et al., 2013). In this study, however, the cropping seasons with maximum and minimum cropped areas under a particular LULC are selected as upper and lower baselines to identify the maximum relative change during the study period. Positive values indicate an increase in cropped area for specific crop year having minimum cultivated area under particular crop and vice versa. Results indicate minimum change in wheat cultivated area for the study period with values ranging from $-16.9 \%$ to $+20.3 \%$. This is mainly driven by its being main staple food in the country, relatively cheaper inputs and reduced chance of crop failure. In contrast, sugarcane has the maximum flexibility in change, i.e., $-38.8 \%$ to $63.5 \%$, while the change for rabi fodder is between $-28.6 \%$ to $40 \%$.

For kharif seasons, rice exhibits minimum variation in cropped area ranging from $-30.55 \%$ and $43.9 \%$. Cotton has a very high volatility in percentage change from $-70.4 \%$ to $238.1 \%$. This extremely large variation is due to recent increase in cotton cultivation during the last cropping season of the study period. The second highest positive change for cotton is $133.4 \%$ during 2010. Results indicate an increasing trend of cotton cultivation in recent years as evinced by Agricultural Outlook Forum (2012) who observed up to $14 \%$ increase in cropped area under cotton in Pakistan compared with that of 2011. It is possibly driven by increased Bt-Cotton cultivation while a shallow change in rice cultivation stems from its excessive water requirements given depleting water resources in the study area. Kharif fodder also shows a clear decreasing trend with positive change in recent years while sugarcane exhibits a change of about $\pm 60 \%$, except $127.2 \%$ in 2007 .

The LULC change detection discussed so far regarding various crops focused only on quantitative changes in cropped areas for whole LCC. It is also important to explore spatial changes in cultivated area for a particular crop during specific cropping season, thus helping to know the allocation of cropped area over time along with potential of a particular crop to replace another one. This end is achieved by performing analysis for change detection considering two different cropping seasons. For this purpose, a number of techniques are helpful such as post-classification comparison, image ratio, image regression and manual onscreen digitization of change. For this study, post classification comparison approach is used, which provides detailed 'From-To' change trajectories at per-pixel level (Lu et al., 2013; Reis, 2008) for each LULC class. Same baseline cropping years as discussed above are used to 
make these comparisons. Area matrices for different crops are constructed and are presented in Tables 8 and 9 .

From the results, the changes in area for major crops can be identified and presented in colored maps. For example, out of total wheat area of 598,403 ha, 120,855 ha are shifted from rabi fodder between years 2007-08 and 2009-10 while the sugarcane area shifted to wheat is 32,161 ha. However, 444,865 ha of land remained under wheat cultivation in both years. This greater value of shared land for wheat between two cropping years shows the preference to wheat cultivation among farmers. The amount of fallow land shifted to wheat remained 476 ha, indicating a prior occupation of most cultivated area by wheat (Table 8). As sugarcane area was higher in 2005-06 as compared to 2010-11 (Table 6), the shared area between the two seasons is 45,465 ha, whereas, the shift from wheat to sugarcane is 4752 ha and 12,150 ha for years 2010-11 and 2005-06, respectively. Similarly, the area shifted from rabi fodder to sugarcane is 19,852 ha and 69,015 ha for years $2010-11$ and 2005-06, respectively. As the area under rabi fodder increased in 2010-11 compared to the previous year, the shared area under this crop is 136,430 ha while an area of 46,500 ha is shifted from sugarcane to rabi fodder. The transfer of wheat area to rabi fodder is maximum, i.e., 116,472 ha (Table 8).

Table 8 Pixel-by-pixel LULC change detection between maximum and minimum cropped areas for rabi seasons

\begin{tabular}{|c|c|c|c|c|c|c|c|c|}
\hline $\begin{array}{l}\text { Crop } \\
\text { class }\end{array}$ & \multicolumn{7}{|c|}{ Change matrix for area (ha) } & Spatial change detection \\
\hline \multirow{7}{*}{ Wheat } & \multicolumn{7}{|c|}{$2007-08$} & \multirow{7}{*}{ 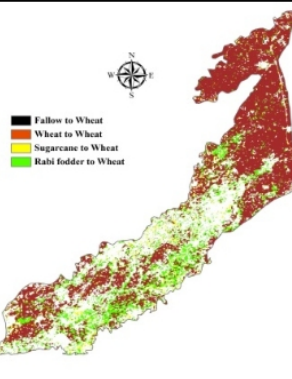 } \\
\hline & \multirow{6}{*}{$\begin{array}{c}2009- \\
10\end{array}$} & & Fallow* & Wheat & S. cane & $\begin{array}{c}\mathrm{R} . \\
\text { fodder }\end{array}$ & Total & \\
\hline & & Fallow* & 14511 & 24 & 1368 & 12 & \multirow{5}{*}{598403} & \\
\hline & & Wheat & 476 & 444865 & 32161 & 120855 & & \\
\hline & & S. cane & 5751 & 3943 & 63460 & 24745 & & \\
\hline & & R. fodder & 0 & 48676 & 29628 & 135526 & & \\
\hline & & Total & & 497546 & & & & \\
\hline \multirow{7}{*}{$\begin{array}{c}\text { Sugarcan } \\
\mathrm{e}\end{array}$} & \multicolumn{7}{|c|}{$2010-11$} & \multirow{7}{*}{ 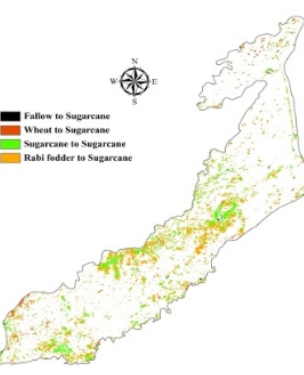 } \\
\hline & \multirow{6}{*}{$\begin{array}{c}2005- \\
06\end{array}$} & & Fallow & Wheat & S. cane & $\begin{array}{c}\mathrm{R} . \\
\text { fodder }\end{array}$ & & \\
\hline & & Fallow & 11959 & 476 & 8361 & 1362 & \multirow{5}{*}{128257} & \\
\hline & & Wheat & 83 & 446441 & 4752 & 97317 & & \\
\hline & & S. cane & 1618 & 12150 & 45465 & 69015 & & \\
\hline & & R. fodder & 24 & 75366 & 19851 & 131762 & & \\
\hline & & Total & & & 78435 & & & \\
\hline \multirow{7}{*}{$\begin{array}{l}\text { Rabi } \\
\text { fodder }\end{array}$} & \multirow{7}{*}{$\begin{array}{c}2010- \\
11\end{array}$} & \multicolumn{6}{|c|}{$2009-10$} & \multirow{7}{*}{ 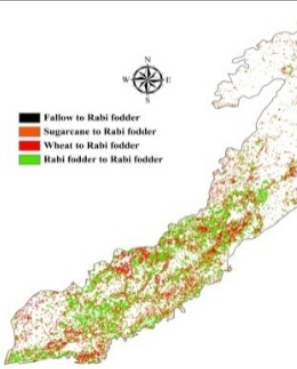 } \\
\hline & & & Fallow & Wheat & S. cane & $\begin{array}{c}\mathrm{R} . \\
\text { fodder }\end{array}$ & Total & \\
\hline & & Fallow & 12001 & 178 & 1505 & 0 & & \\
\hline & & Wheat & 0 & 474773 & 1629 & 58031 & & \\
\hline & & S. cane & 3860 & 6934 & 48266 & 19369 & & \\
\hline & & R. fodder & 54 & 116472 & 46500 & 136430 & 299478 & \\
\hline & & Total & & & & 213847 & & \\
\hline
\end{tabular}


To sum-up, change from fodder to wheat is the highest in LCC and vice versa, as well. Similarly, shift from sugarcane to wheat is conspicuous but is less pronounced in case of wheat to sugarcane. The reason is the annual nature of sugarcane crop with relatively higher water requirements compared with wheat. Farmers find it easy to allocate area from sugarcane to wheat which is otherwise less-attractive. The shifting of area from sugarcane to rabi fodder is the urge on farmers' part to provide a biophysical relief to the soil.

Results of area transformation between crops for kharif seasons are presented in Table 9. It is evident that rice is the major crop occupying a common area of 224,125 ha. This shows a decreased volatility of rice area to shift. The rank-wise contribution of kharif fodder, sugarcane and cotton area to rice area is 88,378 ha, 35,831 ha and 13,726 ha, respectively during 2009. Cotton area also shows increasing trend during recent years. Major contribution to cotton area during 2011 comes from kharif fodder (143,959 ha) and sugarcane (81,034 ha). The area converted from rice to cotton amounts to 25,881 ha. Kharif fodder area has a greater flexibility to be allocated to other crops during the season. Similarly, conversion of cotton area to sugarcane cultivation and vice versa is also observable, whereas change from rice area to cotton and vice versa is less conspicuous.

Table 9 Pixel-by-pixel LULC change detection between maximum and minimum cropped areas for kharif seasons

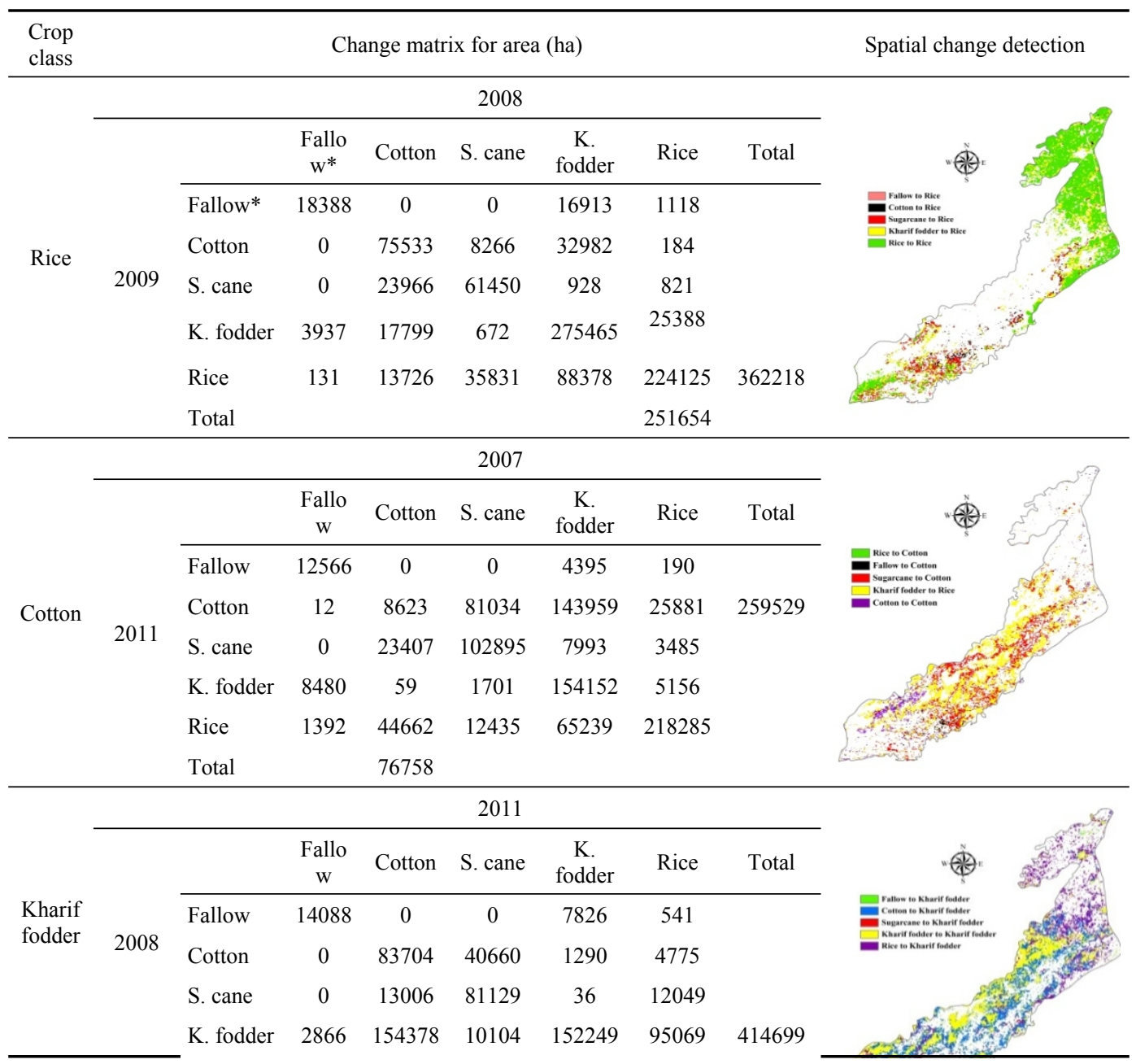




\begin{tabular}{llccccc}
\cline { 3 - 4 } & Rice & 196 & 8421 & 5888 & 7553 & 229578 \\
Total & & \multicolumn{5}{c}{169562} \\
\hline
\end{tabular}

* Fallow/Residential/Barren

\subsubsection{LULC change scenarios for hydrological studies}

The LULC are amongst important environmental factors which are affected heavily by anthropogenic activities and therefore impact the hydrological cycle (Lorencov'a et al., 2013). Evapotranspiration is the single term that links land surface energy balance and surface water balances (Zhao et al., 2013). This forms a key process of hydrological cycle and regarded valuable in water balance modeling especially in irrigated areas (Usman et al., 2015a). Evapotranspiration is generally not considered directly in hydrological studies but as a recharge which varies spatially due to differences in water use for various land uses (Wegehenkel, 2009). As the water balance approach is not perfect without its consideration for evapotranspiration in any agro-climatic region (Usman et al., 2015b), it is estimated by using Surface Energy Balance Algorithm (SEBAL) devised by Bastiannssen et al. (1998b) for its significance in recharge estimation and its application in hydrological studies.

The detailed methodology and application of SEBAL is omitted to save space but it is accessible from Usman et al. (2014). The results of different LULC areal coverage and its change detection as discussed above are correlated with spatially distributed evapotranspiration for establishing patterns of water use within these LULC and to identify potential areas of change for different LULC in all subdivisions of LCC. For this, zonal statistics approach is used to estimate seasonal average water use by different crops in different irrigation subdivisions of LCC as given in Table 10.

Table 10 Irrigation-subdivision wise seasonal average evapotranspiration $(\mathrm{mm})$ and percent of total cultivated area for each LULC class in the study area

\begin{tabular}{|c|c|c|c|c|c|c|c|c|c|c|c|}
\hline LULC & & Sagar & Chuharkana & Paccadala & Mohlan & Buchiana & Tandla & Tarkhani & Kanya & Bhagat & Sultanpur \\
\hline \multirow{2}{*}{ Cotton } & Evapotranspiration & 563.4 & 537.9 & 550.9 & 557.4 & 579.3 & 545.1 & 525.0 & 520.6 & 518.4 & 539.8 \\
\hline & $\%$ area & 1.1 & 2.9 & 5.8 & 11.8 & 15.4 & 21.9 & 13.7 & 14.1 & 9.6 & 3.6 \\
\hline \multirow{2}{*}{ Sugarcane } & Evapotranspiration & 602.1 & 578.4 & 576.1 & 587.5 & 595.0 & 595.1 & 571.9 & 560.8 & 583.5 & 595.3 \\
\hline & $\%$ area & 0.03 & 0.10 & 0.61 & 7.35 & 7.44 & 19.17 & 19.26 & 16.40 & 8.16 & 21.48 \\
\hline \multirow{2}{*}{$\begin{array}{l}\text { Kharif } \\
\text { fodder }\end{array}$} & Evapotranspiration & 529.3 & 525.6 & 513.1 & 534.3 & 544.7 & 516.5 & 482.9 & 505.1 & 460.7 & 530.5 \\
\hline & $\%$ area & 4.1 & 4.6 & 16.7 & 9.9 & 16.6 & 10.2 & 11.7 & 6.9 & 17.8 & 1.6 \\
\hline \multirow{2}{*}{ Rice } & Evapotranspiration & 589.9 & 581.4 & 576.9 & 604.4 & 619.4 & 604.6 & 555.6 & 553.1 & 565.6 & 600.1 \\
\hline & $\%$ area & 30.5 & 24.4 & 9.6 & 16.2 & 0.6 & 2.0 & 2.0 & 1.9 & 7.5 & 5.4 \\
\hline
\end{tabular}

The results of different LULC areal coverage presented in section 3.2.5 represent overall information at LCC scale. In reality, the cultivated area under a particular LULC class is not uniform throughout LCC but specific classes are dominant in particular irrigation subdivisions of LCC. Similarly, LULC change is also not uniform throughout LCC but it is highly dependent on overall areal coverage of a particular class in specific sub-region. Due to this fact and hence to consider spatial variability of any LULC change, total area under any LULC class is segregated at irrigation subdivision level (Table 10). These estimated proportions take into consideration the overall suggested change in any LULC at LCC scale. The potential change from any LULC class to another class is suggested based on the findings 
that appear in Tables 8 and 9.

Subsequently, different LULC scenarios are generated in order to feed their results for future hydrological modeling and to explore their impacts on possible changes in groundwater levels in the study area. To achieve this end, the following two conditions are followed while devising these scenarios:

(1) Ensuring the realistic limits of the area of each LULC class while introducing changes in the area of a particular LULC class based on estimated results (Type I).

(2) Maintaining the area of a particular LULC class within its realistic change limits with no consideration to cropped areas of other classes (Type II).

Along with meeting the above-stated conditions, the following points are considered to ensure maximum suitability of LULC scenarios to the study area:

(a) Change in any LULC class is based on its spatial coverage in any particular sub-region of LCC.

(b) Increase/decrease in LULC area of any particular class is based on its current status in LCC (i.e. year 2011, the latest study year).

(c) LULC change scenarios are based only on classes in kharif cropping seasons as options for change are limited during rabi seasons and the difference in consumptive water use is also less among rabi crops (Usman et al., 2015a; Usman et al., 2014).

Table 11 LULC change scenarios and water utilization (ha-m)

\begin{tabular}{|c|c|c|c|c|c|c|c|c|c|c|c|}
\hline cenario & Type & Sagar & Chuharkana & Paccadala & Mohlan & Buchiana & Tandla & Tarkhani & Kanya & Bhagat & \\
\hline \multirow{2}{*}{$\begin{array}{l}\text { e in Rice area by } \\
\text { vith K.fodder \& }\end{array}$} & & \multicolumn{3}{|c|}{$100 \%$ Rice to K.fodder } & $50 \%$ each to & $100 \%$ Rice & $100 \%$ Rice & \multicolumn{4}{|c|}{$50 \%$ Rice each to K.fodder \& S.ca } \\
\hline & & 1579.6 & 1163.8 & 524.3 & $\begin{array}{l}\text { K.rodaer } \alpha \\
\text { S.cane } \\
\mathbf{( 6 0 0 . 7 )}\end{array}$ & (37.5) & (15.9) & 47.1 & 32.7 & 280.2 & \\
\hline \multirow{2}{*}{$\begin{array}{l}\text { e in Rice area by its } \\
\text { sion to K.fodder }\end{array}$} & & & \multicolumn{3}{|c|}{$100 \%$ Rice to K.fodder } & & \multirow{2}{*}{$\begin{array}{l}100 \% \text { to } \\
\text { S.cane } \\
(\mathbf{1 5 . 9 )}\end{array}$} & \multirow[b]{2}{*}{60.7} & \multicolumn{3}{|c|}{$100 \%$ Rice to K.fodder } \\
\hline & Type-I & 1579.6 & 1163.8 & 524.3 & 484.2 & 37.5 & & & 39.1 & 337.8 & \\
\hline \multirow{2}{*}{$\begin{array}{l}\text { e in Rice area by } \\
\text { vith S.cane }\end{array}$} & & \multicolumn{3}{|c|}{$100 \%$ Rice to K.fodder } & $100 \%$ to & $100 \%$ to & $100 \%$ to & & \multicolumn{3}{|c|}{$100 \%$ Rice to S.cane } \\
\hline & & 1579.6 & 1163.8 & 524.3 & $\begin{array}{l}\text { S.cane } \\
(\mathbf{1 1 6 . 4 )}\end{array}$ & $\begin{array}{l}\text { K.fodder } \\
\text { (37.5) }\end{array}$ & $\begin{array}{l}\text { S.cane } \\
(\mathbf{1 5 . 9 )}\end{array}$ & -13.6 & -6.4 & -57.6 & \\
\hline \multirow{2}{*}{$\begin{array}{l}\text { in Cotton area by } \\
n \text { to S.cane \& }\end{array}$} & & \multicolumn{2}{|c|}{$100 \%$ Cotton to S.cane } & \multicolumn{5}{|c|}{$50 \%$ Cotton each to K.fodder and S.cane } & \multirow{2}{*}{\multicolumn{2}{|c|}{$\begin{array}{l}100 \% \text { to } \\
\text { K.fodder } \\
\text { (722.8) }\end{array}$}} & $100 \%$ \\
\hline & & -56.4 & -151.7 & 47.9 & -53.8 & 189.0 & -305.1 & -43.5 & & & \\
\hline \multirow{2}{*}{$\begin{array}{l}\text { e in Cotton area by } \\
\text { version to S.cane }\end{array}$} & & \multicolumn{8}{|c|}{$100 \%$ Cotton to S.cane } & $100 \%$ to & 100 \\
\hline & Type II & -56.4 & -151.7 & -94.9 & -230.9 & -157.6 & -711.6 & -418.2 & -368.3 & $\begin{array}{c}\text { K.fodder } \\
\mathbf{( 7 2 2 . 8 )}\end{array}$ & \\
\hline \multirow{2}{*}{$\begin{array}{l}\text { e in Cotton area by } \\
\text { version to K.fodder }\end{array}$} & & \multicolumn{2}{|c|}{$100 \%$ to S.cane } & \multicolumn{6}{|c|}{$100 \%$ Cotton to K.fodder } & & $100 \%$ \\
\hline & & -56.4 & -151.7 & 142.8 & 177.1 & 346.6 & 406.4 & 374.7 & 142.4 & 722.8 & \\
\hline \multirow{2}{*}{$\begin{array}{l}\text { in K.fodder by } \\
\text { e, Cotton and }\end{array}$} & \multirow{4}{*}{ Type-I } & \multicolumn{2}{|c|}{$100 \%$ K.fodder from Rice } & \multirow{3}{*}{$\begin{array}{l}50 \% \text { each } \\
\text { from Rice } \\
\text { and Cotton } \\
\text { (718.3) } \\
\text { Rice }\end{array}$} & \multicolumn{5}{|c|}{$50 \%$ K.fodder each from S.cane and Cotton } & \multirow{2}{*}{\multicolumn{2}{|c|}{$\begin{array}{l}50 \% \text { each } \\
\text { from Cotton } \\
\& \text { Rice } \\
(\mathbf{1 2 2 5 . 7 )}\end{array}$}} \\
\hline & & 208.3 & 217.5 & & 320.6 & 595.1 & 462.1 & 650.5 & 209.2 & & \\
\hline \multirow{2}{*}{$\begin{array}{l}\text { in K.fodder by } \\
\text { ement of S.cane \& }\end{array}$} & & \multicolumn{2}{|c|}{$100 \%$ K.fodder from Rice } & & \multicolumn{4}{|c|}{$100 \%$ K.fodder from S.cane } & & \multirow{2}{*}{\multicolumn{2}{|c|}{$\begin{array}{l}100 \% \text { from } K \text {. fod } \\
\mathbf{4 3 5 . 0}\end{array}$}} \\
\hline & & 208.3 & 217.5 & 450.9 & 223.6 & 352.7 & 338.9 & 441.7 & 163.6 & & \\
\hline \multirow{2}{*}{$\begin{array}{l}\text { in K.fodder area } \\
\text { lacement of Cotton }\end{array}$} & & $100 \% \mathrm{~K} . \mathrm{f}$ & er from Rice & \multicolumn{6}{|c|}{$100 \%$ K.fodder from Cotton } & $100 \%$ from & $100 \%$ \\
\hline & & 208.3 & 217.5 & 267.4 & 97.0 & 242.4 & 123.2 & 208.7 & 45.6 & (790.7) & \\
\hline
\end{tabular}


(to be continued on the next page)

The details of different LULC change scenarios and possible water saving or more water utilization against each scenario relative to current water usage are presented in Table 11. The results also provide details of variation for water saving or its more utilization for each irrigation subdivisions under each LULC class along with explaining spatial variability of change. Out of many possible scenarios, 15 scenarios are presented here. These scenarios portray changes in water demand for different LULC changes, thus providing valuable clues regarding their ultimate effect on groundwater table and surface water provision. The last column of Table 11 indicates change in consumptive water use at LCC scale. The negative values depict increased water demand and vice versa under changed land use scenario. Very few scenarios show similar changes in consumptive water use at LCC scale however, the variation of change for each irrigation subdivision is significant and leads to spatial variability of water table. This effect is easily detectable by incorporating these results to hydrological modeling. 


\begin{tabular}{|c|c|c|c|c|}
\hline Sr. No. & Scenario & Type & Sagar & Chuharkana \\
\hline \multirow[t]{2}{*}{10} & \multirow{2}{*}{$\begin{array}{l}30 \% \text { decrease in S.cane area } \\
\text { by its conversion to K.fodder, } \\
\text { Cotton \& Rice }\end{array}$} & \multirow{4}{*}{ Type II } & \multicolumn{2}{|c|}{$\begin{array}{l}50 \% \text { S.cane each to } \\
\text { K.fodder and Rice }\end{array}$} \\
\hline & & & 0.6 & 1.1 \\
\hline \multirow[t]{2}{*}{11} & \multirow{2}{*}{$\begin{array}{l}30 \% \text { increase in S.cane area } \\
\text { by replacing K.fodder, Cotton } \\
\text { \& Rice }\end{array}$} & & \multicolumn{2}{|c|}{$\begin{array}{l}50 \% \text { K.fodder \& } 50 \% \text { Rice } \\
\text { to S.cane }\end{array}$} \\
\hline & & & -0.6 & -1.1 \\
\hline \multirow[t]{2}{*}{12} & $30 \%$ decrease in S.cane area & & & \\
\hline & $\begin{array}{l}\text { by its major conversion to } \\
\text { K.fodder }\end{array}$ & & 0.5 & 1.1 \\
\hline \multirow[t]{2}{*}{13} & $30 \%$ increase in S.cane area & & & \\
\hline & $\begin{array}{l}\text { by its major replacement } \\
\text { from K.fodder }\end{array}$ & Type-I & -0.5 & -1.1 \\
\hline \multirow[t]{2}{*}{14} & $30 \%$ decrease in S.cane area & & \multicolumn{2}{|c|}{$100 \%$ S.cane to Rice } \\
\hline & $\begin{array}{l}\text { by its major conversion to } \\
\text { K.fodder \& Cotton }\end{array}$ & & 0.1 & -0.1 \\
\hline \multirow[t]{2}{*}{15} & $30 \%$ increase in S.cane area & & \multicolumn{2}{|c|}{$100 \%$ Rice to S.cane } \\
\hline & $\begin{array}{l}\text { by its major replacement } \\
\text { from K.fodder \& Cotton }\end{array}$ & Type II & -0.1 & 0.1 \\
\hline
\end{tabular}

Note: Figures in bold show decrease/increase in water utilization under changing $\mathrm{Ll}$

*Change in consumptive water use at LCC scale

Figure12

\section{Conclusions}

Land use/land cover (LULC) change is a global phenomenon and it is accurate and updated information has major significance compulsory for detailed eco-system studies using hydrological modeling. It becomes extremely important in regions dominated by agricultural lands owing to their complexity of use and rapid changes from season to season. In recognition to the role of irrigated agriculture, many global, regional, and country level studies have been conducted varying in space and time scales covering different aspects of crop-water interactions. The present study was conducted in LCC, Pakistan and shows that MODIS $250 \mathrm{~m} \times 250 \mathrm{~m}$ spatial resolution data prove quite useful to discriminate different major LULC. Time series NDVI profiles were constructed and areas under different LULC 
were measured based on this information. This process was repeated for each cropping season separately from year 2005 to year 2012 while considering rabi and kharif as distinct cropping seasons. Different classification accuracy assessment techniques were employed including error matrix, comparison of LULC maps to ancillary data and with previous studies focusing on the study area.

The error matrix analysis shows overall accuracy varying from $79.52 \%$ to $87.39 \%$ for rabi and $76.19 \%$ to $80.08 \%$ for kharif. Kappa coefficients indicate good agreement between actual crop information and classified map information. Kappa values change from 0.66 to 0.77 for individual rabi seasons with an average of 0.73 while range between 0.69 and 0.74 with an average of 0.71 for kharif. The maximum value for coefficient of determination is observed for wheat $(0.85)$ followed by rice $(0.83)$, cotton $(0.78)$ and sugarcane $(0.75)$; showing a potential for replacement of manual data (by government agencies) with remote sensing techniques at spatial resolution of $250 \mathrm{~m} \times 250 \mathrm{~m}$.

Orographic and climatic conditions have specific effects for different crops. For example, the growth conditions for rice and cotton crops are completely different from completely distinct growing areas for both of these crops. Soil with more drainage ability and climates 
with fewer rainfalls are suitable for cotton which is other way round for rice crop. Wheat is cultivated on all types of soils but its cultivation generally starts in relatively warmer months followed by growth stages favoring cooler months. Sowing of sugarcane is mostly adopted in lowsloping areas especially alongside river Ravi.

Based on areal crop coverage data, wheat and rice are ranked first in rabi and kharif cropping seasons, respectively. Overall LULC change detection for individual crops from with respect to maximum and minimum cropped areas indicates wheat as least volatile crop in terms of in cropped area ( $-16.9 \%$ to $20.3 \%)$ during rabi and rice ( $-30.55 \%$ to $43.9 \%)$ in kharif. Cotton exhibits maximum positive change while kharif fodder maximum negative change in recent years. Sugarcane shows a change between $\pm 60 \%$. Spatial LULC change detection at pixel scale indicates that fodder crop has maximum volatility in change compared with all other crops during kharif and rabi seasons. Transformation of cotton area to rice cultivation is less conspicuous but it is remarkably high for sugarcane fodder crops. Change from cotton to rice is less popular but it is more pronounced from sugarcane and fodder to rice.

A number of LULC change scenarios can be proposed based on the classification results for different cropping seasons. These scenarios along with spatio-temporal evapotranspiration explore different options of consumptive water use change.

\section{Acknowledgements}

The authors are thankful to Higher Education Commission (HEC), Pakistan and DAAD, Germany for providing funding to accomplish this study and to all organizations which provided necessary data and logistics to achieve specific objectives of this study. Special thanks to Dr. Jehanzeb Masud Cheema, Assistant Professor, Department of Irrigation \& Drainage, University of Agriculture, Faisalabad, Pakistan for providing technical support.

\section{References}

Agricultural Outlook Forum, 2012. The world and United States cotton outlook. United States Department of Agriculture.

Anderson J R, 1977. Land use and land cover changes: A framework for monitoring. Journal of Research by the Geological Survey, 5: 143-153.

Barraza V, Grings F, Salvia M et al., 2013. Monitoring and modelling land surface dynamics in Bermejo River Basin, Argentina: Time series analysis of MODIS NDVI data. International Journal of Remote Sensing, 34(15): 5429-5451. doi: 10.1080/01431161.2013.791759.

Bastiannssen W G M, 1998a. Remote sensing in water resources management: The state of the art. International Water Management Institute, Colombo, Sri Lanka.

Bastiaanssen W G M, Menenti M, Feddes R A et al., 1998b. A remote sensing surface energy balance algorithm for land (SEBAL) formulation. J. Hydrol., 212/213: 198-212.

Black A, Stephen H, 2014. GIScience \& remote sensing relating temperature trends to the normalized difference vegetation index in Las Vegas. GIScience and Remote Sensing, 51(4): 468-482.

Campbell J B, 2002. Introduction to Remote Sensing. New York: The Guilford Press.

Cheema M J M, Bastiaanssen W G M, 2010. Land use and land cover classification in the irrigated Indus Basin using growth phenology information from satellite data to support water management analysis. Agricultural Water Management, 97(10): 1541-1552. doi: 10.1016/j.agwat.2010.05.009.

Congalton R, Green K, 1999. Assessing the Accuracy of Remotely Sensed Data: Principles and Practices. Boca Raton: CRC/Lewis Press, FL. 137 p.

Congalton R G, 1996. Accuracy assessment: A critical component of land cover mapping in gap analysis: A landscape approach to biodiversity planning. A Peer-Reviewed Proceedings of the ASPRS/GAP Symposium, February 27 - March 2, 1995, Charlotte, N.C. 119-131.

Dappen Patti R, Ratcliffe I C, Robbins C R et al., 2008. Mapping agricultural land cover for hydrologic modeling in 
the Platte River Watershed of Nebraska. Great Plains Research: A Journal of Natural and Social Sciences, Paper 926, http://digitalcommons.unl.edu/greatplainsresearch/926.

Ding H, Shi W, 2013. Land-use/land-cover change and its influence on surface temperature: A case study in Beijing City. International Journal of Remote Sensing, 34(15): 5503-5517. doi: 10.1080/01431161.2013.792966.

Douglas K B, Mark A F, 2013. Forecasting crop yield using remotely sensed vegetation indices and crop phenology metrics. Agricultural and Forest Meteorology, 173: 74-84.

Fang W, Chen J, Shi P, 2005. Variability of the phenological stages of winter wheat in the North China Plain with NOAA/AVHRR NDVI data (1982-2000). IEEE International Geoscience and Remote Sensing Symposium Proceedings, 5: 3124-3127.

Fisher P F, 2010. Remote sensing of land cover classes as type 2 fuzzy sets. Remote Sensing of Environment, 114: 309-321.

Foody G M, 2002. Status of land cover classification accuracy assessment. Remote Sensing of Environment, 80: 185-201.

Gao X, Huete A R, Ni W et al., 2000. Optical-biophysical relationships of vegetation spectra without back-ground contamination. Remote Sensing of Environment, 74: 609-620.

Giri, Chandra, Jenkins C, 2005. Land cover mapping of greater Mesoamerica using MODIS data. Remote Sensing, 31(4): 274-282. Retrieved at http://thepimmgroup.org/wp-content/uploads/2007/11/remotesensing2.pdf.

Gong P, Wang J, Yu L et al., 2013. Finer resolution observation and monitoring of global land cover: First mapping results with Landsat TM and ETM+ data. International Journal of Remote Sensing, 34(7): 2607-2654. doi: 10.1080/01431161.2012.748992.

Gumma M K, Nelson A, Thenkabail P S et al., 2011. Mapping rice areas of South Asia using MODIS multitemporal data. J. Applied Remote Sensing, 5(1): 53547. doi: 10.1117/1.3619838.

Jensen J R, 1996. Introductory Digital Image Processing: A Remote Sensing Perspective. 2nd ed. New Jersey: Prentice-Hall, 316p.

Jeong S, Jang K, Hong S et al., 2011. Detection of irrigation timing and the mapping of paddy cover in Korea using MODIS images data. Korean Journal of Agricultural and Forest Meteorology, 13: 69-78.

Julien Y, Sobrino J A, 2009. Global land surface phenology trends from GIMMS database. International Journal of Remote Sensing, 30: 3495-3513.

Kim, Y. 2013. Drought and elevation effects on MODIS vegetation indices in northern Arizona ecosystems. International Journal of Remote Sensing, 34(14): 4889-4899. doi: 10.1080/2150704X.2013.781700.

Kimaro T A, Tachikawa Y, Takara K, 2005. Distributed hydrologic simulations to analyze the impacts of land use changes on flood characteristics in the Yasu River Basin in Japan. Journal of Natural Disaster Sciences, 27(2): 85-94.

Latifovic R, Olthof I, 2004. Accuracy assessment using sub-pixel fractional error matrices of global land cover products derived from satellite data. Remote Sensing of Environment, 90: 153-165.

Leff B, Ramankutty N, Foley J A, 2004. Geographic distribution of major crops across the world. Global Biogeochem. Cycles, 18, GB 1009. doi: 10.1029/203GB002108.

Liang L, Gong P, 2013. Evaluation of global land cover maps for cropland area estimation in the conterminous United States. International Journal of Digital Earth: 1-16. doi: 10.1080/17538947.2013.854414.

Lorencov' A E, Fr' Elichov' A J, Nelson E et al., 2013. Past and future impacts of land use and climate change on agricultural ecosystem services in the Czech Republic. Land Use Policy, 33: 183-194.

Lu D, Li G, Moran E et al., 2013. Spatiotemporal analysis of land use and land cover change in the Brazilian Amazon. International Journal of Remote Sensing, 34(16): 5953-5978. doi:10.1080/01431161.2013.802825.

Matthews E, 1983. Global vegetation and landuse: New high resolution data bases for climate studies. Journal of Climate and Applied Meteorology, 22: 474-487.

Mitrakis N E, Mallinis G, Koutsias N et al., 2011. Burned area mapping in Mediterranean environment using medium-resolution multi-spectral data and a neuro-fuzzy classifier. International Journal of Image and Data Fusion, 1-20.

Molden D, 1997. Accounting for water use and productivity. SWIM paper 1. Colombo, Srilanka.

Morton D C, DeFries R S, Shimabukuro Y E et al., 2006. Cropland expansion changes deforestation dynamics in the southern Brazilian Amazon. Proceedings of the National Academy of Sciences of the United States of America, 103(39): 14637-14641.

Niu Z, Zhang H, Wang X et al., 2012. Mapping wetland changes in China between 1978 and 2008. Chinese Science Bulletin, 57(22): 2813-2823. doi: 10.1007/s11434-012-5093-3.

Osborne P, Alonso J, Bryant R, 2001. Modelling landscape-scale habitat use using GIS and remote sensing: A case study with great bustards. Journal of Applied Ecology, 38: 458-471.

Oslon J S, 1994. Global ecosystem framework definitions. USGS EROS Data Center Internal Report, Sioux Falls, SD, 37p. 
Peng D, Huete A R, Huang J et al., 2011. Detection and estimation of mixed paddy rice cropping patterns with MODIS data. International Journal of Applied Earth Observation and Geoinformation, 13: 13-23.

Pettorelli N, 2013. The Normalized Difference Vegetation Index. Oxford: Oxford University Press.

Portmann F T, Siebert S, Döll P, 2010. MIRCA2000-Global monthly irrigated and rainfed crop areas around the year 2000: A new high-resolution data set for agricultural and hydrological modeling. Global Biogeochemical Cycles, 24: GB1011.

Prakasam C, 2010. Land use and land cover change detection through remote sensing approach: A case study of Kodaikanal taluk, Tamil nadu. International Journal of Geomatics and Geosciences, 1(2): 150-158.

Reed B C, Brown J F, VanderZee D et al., 1994. Measuring phenological variability from satellite imagery. Journal of Vegetation Science, 5: 703-714.

Reis S, 2008. Analyzing land use/land cover changes using remote sensing and GIS in Rize, North-East Turkey. Sensors, 8(10): 6188-6202. doi: 10.3390/s8106188.

Schilling K E, Jha M K, Zhang Y et al., 2008. Impact of land use and land cover change on the water balance of a large agricultural watershed: Historical effects and future directions. Water Resources Research, 44(7): 1-12. Available at: http://doi.wiley.com/10.1029/2007WR006644 [Accessed October 8, 2014].

Shao Y, Fan X, Liu H et al., 2001. Rice monitoring and production estimation using multitemporal RADARSAT. Remote Sensing of Environment, 76(3): 310-325. doi: 10.1016/S0034-4257(00)00212-1.

Shi J, Huang J, Zhang F, 2013. Multi-year monitoring of paddy rice planting area in Northeast China using MODIS time series data. Journal of Zhejiang University (Science B), 14(10) (October): 934-946. doi: 10.1631/jzus.B1200352.

Thi T, Nguyen H, De-Bie C A J M et al., 2012. Mapping the irrigated rice cropping patterns of the Mekong delta, Vietnam, through hyper-temporal SPOT NDVI image analysis. International Journal of Remote Sensing, 33(2): $415-434$.

Tou J T, Gonzalez R C, 1974. Pattern Recognition Principles. London: Addison-Wesley, 1974.

Tucker C J, 1979. Red and photographic infrared linear combinations for monitoring vegetation. Remote Sensing of Environment, 8: 127-150.

Tucker C J, Vanpraet C L, Sharman M J et al., 1985. Satellite remote sensing of total herbaceous biomass production in the Senegalese Sahel: 1980-1984. Remote Sensing of Environment, 17: 233-249.

Usman M, Liedl R, Awan U K, 2015a. Spatio-temporal estimation of consumptive water use for assessment of irrigation system performance and management of water resources in irrigated Indus Basin, Pakistan. J. Hydrol. doi: 10.1016/j.jhydrol.2015.03.031.

Usman M, Liedl R, Kavousi A, 2015b. Estimation of distributed seasonal net recharge by modern satellite data in irrigated agricultural regions of Pakistan. Environ. Earth Sciences. doi: 10.1007/s12665-015-4139-7.

Usman M, Liedl R, Shahid M A M, 2014. Managing irrigation water by yield and water productivity assessment of a rice-wheat system using remote sensing. Journal of Irrigation and Drainage Engineering. doi: 10.1061/(ASCE)IR.1943-4774.0000732.

Wajid A, Ahmad A, Khaliq T et al., 2010. Quantification of growth, yield and radiation use efficiency of promising cotton cultivars at varying nitrogen levels. Pakistan Journal of Botany, 42(3): 1703-1711.

Wajid A, Hussain K, Maqsood M et al., 2007. Simulation modeling of growth, development and grain yield of wheat under semi arid conditions of Pakistan. Pakistan Journal of Agricultural Sciences, 44(2): 194-199.

Wardlow B D, Egbert S L, Kastens J H, 2007. Analysis of time-series MODIS $250 \mathrm{~m}$ vegetation index data for crop classification in the U.S. Central Great Plains. Drought Mitigation Center Faculty Publications. Paper 2. http://digitalcommons.unl.edu/droughtfacpub/2.

Wegehenkel M, 2009. Modeling of vegetation dynamics in hydrological models for the assessment of the effects of climate change on evapotranspiration and groundwater recharge. Adv. Geosci., 21: 109-115. doi: 10.5194/adgeo21-109-2009.

Wilson M, Henderson-Sellers A, 1985. A global archive of land cover and soils data for use in general circulation models. Journal of Climatology, 5: 119-143.

Xiao X, Boles S, Frolking S et al., 2006. Mapping paddy rice agriculture in South and South-east Asia using multitemporal MODIS images. Remote Sensing of Environment, 100: 95-113. http://dx.doi.org/10.1016/ j.rse.2005.10.004.

Yu L, Wang J, Gong P, 2013. Improving $30 \mathrm{~m}$ global land-cover map FROM-GLC with time series MODIS and auxiliary data sets: A segmentation-based approach. International Journal of Remote Sensing, 34(16): 58515867. doi: 10.1080/01431161.2013.798055.

Zhao L, Xia J, Xu C et al., 2013. Evapotranspiration estimation methods in hydrological models. J. Geogr. Sciences, 23(2): 359-369. doi: 10.1007/s11442-013-1015-9.

Zheng P Q, Baetz B W, 1999. GIS-based analysis of development options from a hydrology perspective. Journal of Urban Planning and Development, 125: 164-180. 